\title{
ANÁLISE GENÉTICA DA TAXA DE CRESCIMENTO E DO DESEMPENHO REPRODUTIVO EM GALINHAS PARA CORTE
}

\section{Antonio Augusto Domingos Coelho}

Engenheiro Agrônomo

Orientador: Prof. Dr. RANDOLFO WILLIAM SILVESTRE CUSTÓDIO

\begin{abstract}
Tese apresentada à Escola Superior de Agricultura "Luiz de Queiroz", Universidade de São Paulo, para obtenção do título de Doutor em Agronomia, Área de Concentração: Genética e Melhoramento de Plantas.
\end{abstract}

PIRACICABA

Estado de São Paulo - Brasil

Agosto - 1997 
Dados Internacionais de Catalogação na Publicação (CIP) DIVISÃO DE BIBLIOTECA E DOCUMENTAÇÃO - Campus "Luiz de Queiroz"/USP

\section{Coelho, Antonio Augusto Domingos} Análise genética da taxa de crescimento e do desempenho reprodutivo em galinhas para corte / Antonio Augusto Domingos Coelho. - - Piracicaba, 1997. 74 p. : ll.

Tese (doutorado) - Escola Superior de Agricultura Luir de Queiroz, 1997. Bibliografia.

1. Galinha de corte (desempenho) 2. Melhoramento 3. Vari bilidade genética 


\section{ANÁliSE GENÉTICA DA TAXA DE CRESCIMENTO E DO DESEMPENHO REPRODUTIVO EM GALINHAS PARA CORTE}

\section{ANTONIO AUGUSTO DOMINGOS COELHO}

Aprovada em: 25.09.1997

Comissão julgadora:

Prof. Dr. Randolfo William Silvestre Custódio

Prof. Dr. Irineu Umberto Packer

Prof. Dr. Gerhard Bandel

Prof $^{a} \operatorname{Dr}^{a}$ Maria Inês Tirabofchi Ferro

Prof. Dr. Alcides Amorin Ramos
ESALQ / USP

ESALQ / USP

ESALQ / USP

FCAVJ / UNESP

FMVZ / UNESP

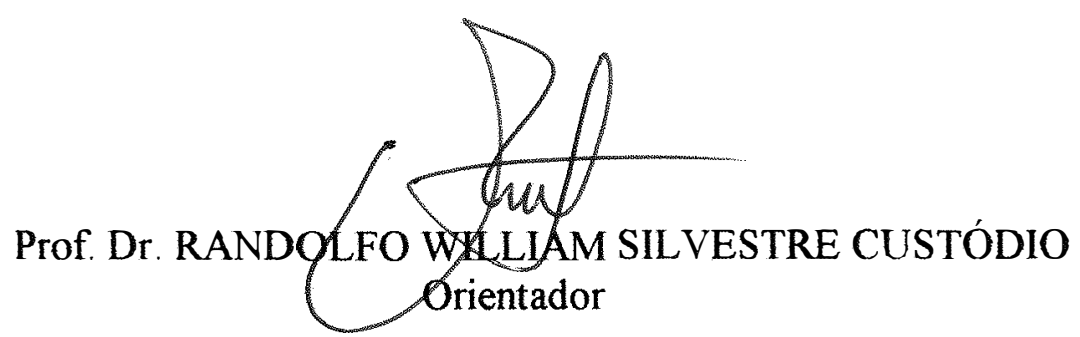


Em homenagem aos meus pais,

\section{ANTONIO AUGUSTO COELHO \\ AMÉLA DOMINGOS COELHO}

À minha esposa IZILDINHA,

o autor dedica este trabalho

e o oferece a seus filhos: LUCAS

\section{LEANDRO}




\section{AGRADECIMENTOS}

Ao Professor Dr. Randolfo William Silvestre Custódio, pela orientação na condução deste trabalho.

Ao Professor Dr. Irineu Umberto Packer, pela indispensável colaboração no planejamento e execução das análises estatísticas.

Ao Professor Dr. Roland Vencovsky, pelo apoio e incentivo na elaboração deste trabalho.

Ao Professor Dr. Gerhard Bandel, pelo apoio recebido durante a realização do Curso de Doutorado.

Aos Professores do Curso de Pós-Graduação em "Genética e Melhoramento de Plantas", pelos ensinamentos ministrados.

Ao Professor Dr. Vicente José Maria Savino, pela indispensável amizade e colaboração para a realização deste trabalho.

Ao Professor Dr. Jossi Hillel, pela orientação e apoio na execução das análises laboratoriais.

Aos Professores Dr. Geraldo Antonio Tosello e Dr. Flávio César Almeida Tavares, pelo apoio na execução das análises laboratoriais.

Ao Dr. Sérgio Echeverrigaray Laguna, pelo apoio na execução das análises laboratoriais.

Ao Dr. Paulo Hellmeister Filho pela colaboração na realização deste trabalho.

Ao Biólogo Luiz Humberto Gomes, pelo apoio na execução das análises laboratoriais.

Ao Professor Gabriel Adrian Sarriez, pelo assessoramento nas análises estatísticas.

Ao Analista de Sistemas Carlos Roberto Macedonio, pela indispensável colaboração na execução das análises estatísticas.

Aos Funcionários do Setor de Aves do Departamento de Genética, pela indispensável colaboração na condução dos experimentos e coleta de dados.

Aos Técnicos Márcio e Alexandre, pela colaboração no processamento do texto deste trabalho.

A FINEP e ao CNPq pela concessão de recursos para a realização deste trabalho.

A todos aqueles que direta ou indiretamente, contribuíram para a realização deste trabalho.

A DEUS, por estar sempre presente e iluminando o meu caminho. 


\section{SUMÁRIO}

LISTA DE FIGURAS ........................................................ vi

LISTA DE TABELAS …..................................................... viii

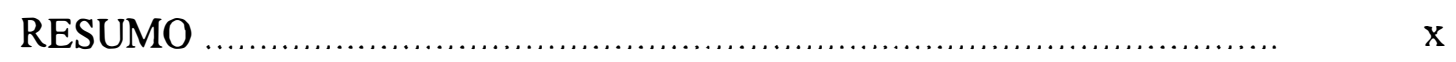

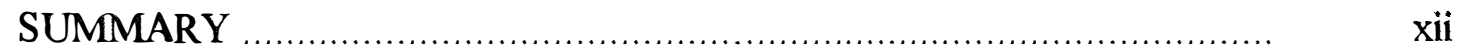

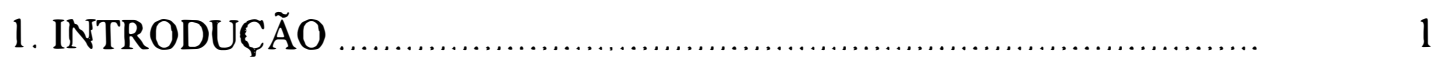

2. REVISÃO DE LITERATURA ….................................................. 4

2. 1 Parâmetros genéticos e fenotípicos............................................

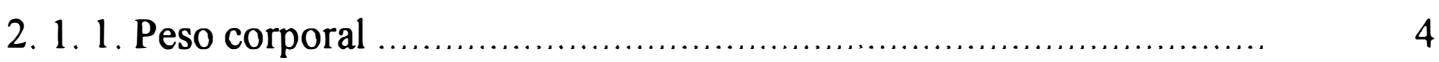

2. 1. 2. Taxa reprodutiva ............................................................ 5

2. 1. 2. 1. Repetibilidade e herdabilidade ......................................... 6

2. 1. 2. 2. Correlações genéticas, fenotípicas e ambientais ........................ 7

2. 2. Variabilidade genética e "DNA fingerprinting" ............................... 10

3. MATERIAIS E MÉTODOS ..................................................... 15

3. 1. Obtenção de parâmetros genéticos e fenotípicos .............................. 15

3. 1. 1. Análises da taxa de crescimento ........................................... 16

3. 1. 1. 1. Avaliações do peso corporal ............................................... 16

3. 1. 1. 2. Obtenção de repetibilidades .................................................. 19

3. 1. 2. Análises dos desempenhos reprodutivos ................................... 21

3. 2. Análises da variabilidade genética através do DNA fingerprinting....... 25

3. 2. 1. Extração de DNA das aves ..................................................... 25

3. 2. 2. Digestão do DNA e separação em gel ........................................ 27

3. 2. 3. Transferência do DNA para membrana de nylon .......................... 28

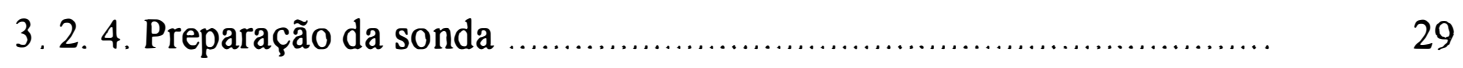

3. 2. 5. Hibridização ….................................................................. 32

3. 2. 6. Obtenção da autoradiografia ............................................... 32

3. 2. 7. Avaliação dos perfis ........................................................ 33

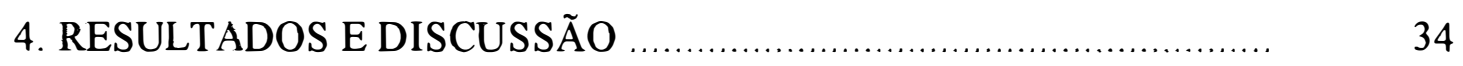


4. 1. Análise da taxa de crescimento .................................................

4. 1. 1. Estimativas de repetibilidade ................................................... 39

4. 2. Análises dos desempenhos reprodutivos ....................................... 41

4. 2. 1. Avaliação do desempenho reprodutivo .................................... 41

4. 2. 2. Determinação de parâmetros genéticos e fenotípicos para características reprodutivas ................................................... 48

4. 2. 2. 1. Estimativas de herdabilidade ................................................. 48

4. 2. 2. 2. Correlações genéticas, fenotípicas e ambientais ....................... 50

4. 3. Análises da variabilidade genética através do "DNA fingerprinting".... 52

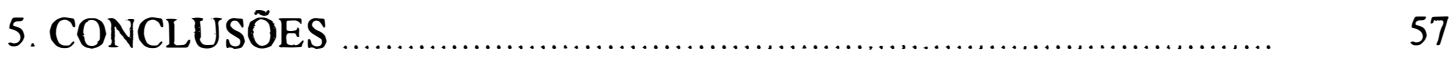

REFERÊNCIAS BIBLIOGRÁFICAS …....................................... 59

APÊNDICE 


\section{LISTA DE FIGURAS}

Página

1. Representação esquemática do sistema montado para a transferência de DNA para membrana de nylon

2. Peso médio (gramas) aos 28 dias de idade das linhagens experimentais e do material comercial

3. Representação gráfica dos contrastes envolvendo as médias do peso corporal entre o material comercial (MC) e os diferentes grupos das linhagens experimentais [(IPEG)1, (IPEG)2 e (IPEG)3]

4. Peso médio (gramas) aos 28 e 35 dias de idade das 12 linhagens experimentais

5. Valores médios verificados para as características Número de Ovos Incubados (NOI), Número de Ovos Férteis (NOF) e Número de Pintos Nascidos (NPTS), na avaliação do desempenho reprodutivo das linhagens

6. Valores médios verificados para as características Fertilidade \% (FERT), Eclodibilidade \% (ECLOD) e Nascimento \% (NASC), na avaliação do desempenho reprodutivo das linhagens

7. Representação gráfica dos contrastes entre os diferentes grupos das linhagens experimentais [(IPEG) 1, (IPEG)2 e (IPEG)3], envolvendo as médias das características NOI, NOF, NPTS, FERT, ECLOD e NASC . 
8. Perfis polimórficos obtidos nas análises de DFP das linhagens experimentais

9. Representação esquemática do padrão de distribuição das 24 bandas mais representativas das amostras de DNA das linhagens

10. Dendograma com as 12 linhagens agrupadas em função dos índices de similaridade (BS) 


\section{LISTA DE TABELAS}

Página

1. Correlações genéticas, fenotípicas e ambientais entre as características reprodutivas encontradas na literatura

2. Composição das rações utilizadas no período de avaliação do peso corporal

3. Esquemas de arraçoamento e iluminação adotados no manejo das aves utilizadas na avaliação do desempenho reprodutivo

22

4. Composição das rações de recria e reprodução utilizadas

5. Análise de variância do peso corporal aos 28 dias de idade das aves das linhagens experimentais e do material comercial

6. Comparação das médias do peso corporal aos 28 dias das linhagens experimentais e do material comercial

7. Pesos médios corporais aos 28 dias de idade das 16 incubações

8. Limites superiores e inferiores dos pesos médios corporais aos 28 dias de idade, para cada sexo, nos materiais avaliados

9. Análise de variância do peso corporal das 12 linhagens experimentais no período de 28 a 35 dias de idade

10. Estimativas de repetibilidade e erro padrão (E.P.) para peso corporal no período de 28 a 35 dias de idade das linhagens experimentais 
11. Análise de variância das características Número de Ovos Incubados (NOI), Número de Ovos Férteis (NOF) e Número de Pintos Nascidos (NPTS)

12. Análise de variância das características Fertilidade \% (FERT), Eclodibilidade \% (ECLOD) e Nascimento \% (NASC)

13. Teste de médias (least-squares) estimadas para as características Número de Ovos Incubados (NOI), Número de Ovos Férteis (NOF) e Número de Pintos Nascidos (NPTS)

14. Teste de médias (least-squares) estimadas para as características Fertilidade \% (FERT), Eclodibilidade \% (ECLOD) e Nascimento \% (NASC)

15. Estimativas de herdabilidade $\left(\mathrm{h}^{2}\right)$ para as características reprodutivas NOI, NOF, NPTS, FERT, ECLOD e NASC

16. Correlações genéticas $\left(\mathrm{r}_{\mathrm{g}}\right)$ com desvios-padrão, e correlações fenotípicas $\left(r_{f}\right)$ e ambientais $\left(r_{a}\right)$, entre as características NOI, NOF, NPTS, FERT, ECLOD e NASC

17. Índices de similaridade (bandsharing) calculados com base nas análises de DFP das linhagens 


\title{
ANÁLISE GENÉTICA DA TAXA DE CRESCIMENTO E DO DESEMPENHO REPRODUTIVO EM GALINHAS PARA CORTE
}

\author{
Autor: ANTONIO AUGUSTO DOMINGOS COELHO \\ Orientador: Prof. Dr. RANDOLFO WILLIAM SILVESTRE CUSTÓDIO
}

\section{RESUMO}

A pesquisa foi realizada no Departamento de Genética da ESALQ / USP, em Piracicaba, SP, utilizando linhagens nacionais de galinhas para corte, com os objetivos de: a) avaliar o estado atual dos desempenhos reprodutivos e peso juvenil das linhagens; b) determinar a magnitude de parâmetros genéticos e fenotípicos da taxa de crescimento e desempenho reprodutivo das linhagens; c) verificar o nível de variabilidade genética existente entre as linhagens através de análises de variância e de índices de similaridade.

Para avaliar o estágio de desenvolvimento do peso corporal das linhagens, foram pesadas individualmente ao completarem 28 dias de idade, 4565 aves originadas em 16 incubações semanais consecutivas. A título de comparação foram avaliadas também 1093 aves provenientes de ovos férteis produzidos por matrizes comerciais. A determinação de estimativas de repetibilidade para o peso corporal foi realizada com uma amostra casualizada de 526 aves, de ambos os sexos, das 12 linhagens experimentais, obtida na avaliação do peso corporal aos 28 dias de idade. Essas aves foram novamente pesadas aos 35 dias de idade para a obtenção de repetibilidades em modelo que envolveu efeitos fixos (linhagens) e aleatórios (aves dentro de linhagem). 
aos 35 dias de idade para a obtenção de repetibilidades em modelo que envolveu efeitos fixos (linhagens) e aleatórios (aves dentro de linhagem).

A obtenção de parâmetros genéticos e fenotípicos para as características número de ovos incubados (NOI), número de ovos férteis (NOF), número de pintos nascidos (NPTS), fertilidade \% (FERT), eclodibilidade \% (ECLOD) e nascimento \% (NASC) associadas aos desempenhos reprodutivos das linhagens, foi realizada com 1908 observações registradas durante 16 incubações semanais consecutivas. Estimativas de herdabilidade e correlações genéticas, fenotípicas e ambientais entre as características reprodutivas foram obtidas através de modelo que envolveu efeitos fixos (linhagens e incubações) e aleatórios (galinhas dentro de linhagens).

Análises laboratoriais pela técnica do "DNA fingerprinting" (DFP) proporcionaram a obtenção de polimorfismos de DNA, com os quais se calcularam índices de similaridade (bandsharing) equivalentes as distâncias genéticas entre as linhagens que permitiram avaliar a variabilidade genética existente entre as mesmas.

Concluiu-se do presente estudo que: a) a repetibilidade verificada para o peso corporal das linhagens no período de 28 a 35 dias de idade foi elevada, existindo boas perspectivas de melhoramento genético da taxa de crescimento através de seleção massal; b) as estimativas de herdabilidade para as características reprodutivas foram de pequena magnitude; c) as elevadas correlações genéticas entre as características NOF x NPTS e ECLOD x NASC indicam que esses caracteres são praticamente idênticos; d) as análises de DFP comprovaram a existência de nível expressivo de variabilidade genética entre as linhagens. 


\title{
GENETIC ANALYSIS FOR GROWTH RATE AND REPRODUCTIVE PERFORMACE IN MEAT-TYPE CHICKENS
}

\author{
Author: ANTONIO AUGUSTO DOMINGOS COELHO
}

Adviser: Prof. Dr. RANDOLFO WILLIAM SILVESTRE CUSTÓDIO

\section{SUMMARY}

This research was carried out at the Genetic Department of ESALQ / USP, in Piracicaba, SP, with brazilians lines of meat - type chickens. The objectives were: a) to evaluated the reproductive performance and juvenile weight of lines; b) to determine the overall magnitude of genetic and phenotypic parameters for growth rate and reproductive performance of lines, c) to evaluate the genetic variability between lines through variance analysis and similarity index.

In order to evaluate the growth rate of each line 4565 progenies were produced in sixteen consecutive hatches produced weekly and the birds were individually weighted at 28 days of age. One thousand and ninety and three commercial broilers were also evaluated to be compared with the lines. Repeatabilities estimates for body weight were obtained from a randomized sample of 526 progenies of twelve experimental lines. Overall repeatabilities estimates were obtained by weighting individual birds at 28 and 35 days of age. The statistical model included lines as fixed effects and individual birds within line as random effects. 
Phenotypic and genetic parameters overall lines were obtained using 1908 observations taken from 16 weekly consecutive hatches for number of eggs hatched (NOI), number of fertile eggs (NOF), number of chicks hatched (NPTS), percentage of fertile eggs (FERT), percentage hatch of fertile eggs (ECLOD) and hatchability of all eggs set (NASC). Heritability estimates and genetic, phenotypic and environmental correlations between reproductive traits were obtained by using a model in which was involved fixed effects (lines and hatches) and random effects (dam within line).

DNA polymorphisms were obtained from DNA fingerprinting (DFP) analysis and these results were utilized for evaluated the genetic variability between lines through bandsharing (a similarity index).

The main conclusions obtained were: a) repeatabilities for body weight from 28 to 35 days was high, indicating good prospects for genetic improvement of growth rate by individual selection; b) heritability estimates for reproductive traits were small; c) the high genetic correlations between NOF $x$ NPTS and ECLOD $x$ NASC indicated that these traits are virtually identical; d) the DFP analysis confirmed the existence of expressive genetic variability between lines. 


\section{INTRODUÇÃO}

A produtividade das aves destinadas à produção de carne é função de inúmeras características. Dos reprodutores se exige elevada capacidade de fertilização e alta produção de ovos de excelente qualidade que permitam obter altas taxas de fertilidade e viabilidade embrionária, gerando pintos viáveis. Em função de um direcionamento genético adequado, esses pintos devem responder a nível de campo, com elevada taxa de crescimento, alta viabilidade e eficiente conversão alimentar, proporcionando ainda no abate grande rendimento de carcaça. O desenvolvimento de materiais genéticos com essas características de desempenho vem sendo controlado em todo o mundo por um número relativamente pequeno de empresas.

O peso corporal, em função do seu valor econômico, tem sido uma das características mais importantes na avaliação do desempenho de linhagens comerciais de aves para corte (Schmidt et al., 1992). Durante os últimos 50 anos, a seleção para taxa de crescimento foi altamente eficiente no fornecimento de linhagens de elevado desempenho para a produção de carne. No entanto, sabendo-se que as características de crescimento e de reprodução são geneticamente antagônicas (Kinney Júnior \& Shoffner, 1965), espera-se que a seleção genética para crescimento rápido possa provocar uma queda no desempenho reprodutivo de galinhas para corte. 
Diversas linhagens de galinhas para corte, obtidas há cerca de 15 anos, vêm sendo atualmente utilizadas no Programa de Melhoramento Genético Avícola da ESALQ. Nesse período, essas linhagens foram submetidas à intensa seleção com respostas genéticas expressivas, razão pela qual supõe-se que esteja ocorrendo também uma redução na variabilidade genética das mesmas. A seleção para características de importância econômica e de herdabilidade alta tais como: peso corporal e peso do ovo, provocam um estreitamento da base genética e por consequência uma redução na variabilidade genética (Siegel et al., 1992; Munari et al., 1992). Como a continuidade do progresso genético no aumento do crescimento e produção de ovos depende essencialmente da variabilidade genética, o conhecimento do estado atual desta é de grande interesse.

Estimativas de parâmetros genéticos e fenotípicos para diversas características de interesse econômico em linhagens de aves para corte são descritas com frequência na literatura, porém, em programas específicos de seleção, essas estimativas necessitam ser determinadas e monitoradas rotineiramente (Ledur et al., 1994). Por outro lado, o desenvolvimento de técnicas para o estudo do DNA abriu novas fronteiras no campo da genética e melhoramento animal. A grande sensibilidade dessas técnicas associada à descoberta de regiões do DNA com alto grau de variabilidade vem permitindo avanços significativos nos estudos de polimorfismo em populações. A exploração do polimorfismo ao nível da variação na sequência de bases do DNA foi proposta pela primeira vez no início da década passada (Botstein et al., 1980), quando as variações detectadas na sequência de DNA foram chamadas de polimorfismo (diferenças) no tamanho dos fragmentos de restrição ou RFLP ("restriction fragment length polymorphism"). Desde então, várias metodologias que revelam a existência de polimorfismos moleculares têm sido descritas na literatura.

A partir dos trabalhos de Jeffreys et al. (1985a,b), as análises de "DNA fingerprinting" (DFP) caracterizadas pela utilização de sondas capazes de hibridizar 
com regiōes repetitivas hipervariáveis, distribuídas no genoma de organismos eucariotos têm se tornado um dos principais sistemas de identificação de indivíduos e/ou linhagens com inúmeras aplicações no melhoramento. O uso do DFP é eficaz na identificação de indivíduos em populações de aves (Burke \& Bruford, 1987) e na avaliação de relações genéticas entre e dentro de populações (Kuhnlein et al., 1989; Dunnington et al., 1990; Siegel et al., 1992).

Os objetivos deste trabalho foram:

a) avaliar o estado atual dos desempenhos reprodutivos e peso juvenil em linhagens de galinhas para corte selecionadas para maior taxa de crescimento;

b) determinar a magnitude de parâmetros genéticos e fenotípicos da taxa de crescimento e desempenho reprodutivo das linhagens selecionadas para corte;

c) verificar o nível de variabilidade genética existente entre as linhagens de galinhas para corte em desenvolvimento na ESALQ, através de análises de variância e de DFP's. 


\section{REVISĀO DE LITERATURA}

\subsection{Parâmetros genéticos e fenotípicos}

\subsubsection{Peso corporal}

$\mathrm{Na}$ avaliação de linhagens de galinhas para corte a característica peso corporal é de fundamental importância, devido a sua participação no custo de produção e seu reflexo em programas de seleção. Para essa característica são relatadas na literatura, herdabilidades de média a alta magnitude. Siegel (1962), analisando 176 publicações referentes a estimativas de herdabilidade do peso corporal de galinhas de 6 a 12 semanas de idade, obteve um valor médio de 0,41 com uma variação interquartil na faixa de 0,29 a 0,54. Moyer et al. (1962) trabalhando com progênies híbridas provenientes de duas linhagens de corte, obtiveram estimativas de herdabilidade para peso corporal aos 28 dias de idade variando de 0,19 a 0,99 . Para essa mesma idade, Siegel $(1963 a, b)$ encontrou estimativas de herdabilidade para esse caráter variando de 0,43 a 0,53 em linhagens de "White Plymouth Rocks".

Zaborowsky et al. (1977 e 1978) pesquisando a herdabilidade da taxa de crescimento em três populações de galinhas para corte desenvolvidas na ESALQ/USP, determinaram estimativas variando de 0,14 a 0,38 para a idade de oito semanas. Aos 35 dias de idade, Pym \& Nicholls (1979) obtiveram estimativas de herdabilidade para peso corporal variando de 0,63 até valores próximos a 1,0. 
Becker et al. (1984) trabalhando com progênies de linha fêmea de galinhas para corte, obtiveram estimativas de herdabilidade do peso vivo corporal aos 50 dias de idade, variando de 0,23 a 0,88. Estimando parâmetros genéticos e fenotípicos para peso corporal de duas linhagens de galinhas para corte, em desenvolvimento no CNPSA/EMBRAPA, em diferentes idades, Ledur et al. (1992) obtiveram as seguintes estimativas de herdabilidade: 0,34 a 0,56 com 28 dias, 0,28 a 0,63 com 35 dias e 0,27 a 0,56 com 42 dias de idade. Em estudo de mesma natureza, Schmidt et al. (1992) encontraram estimativas de herdabilidade em torno de 0,30 para peso aos 42 dias de idade, de linhagens de galinhas para corte. De modo semelhante, Ledur et al. (1994) obtiveram estimativas de herdabilidade variando de 0,26 a 0,44 para fêmeas da linha fêmea, com relação ao peso corporal aos 42 dias de idade, de duas linhagens de galinhas para corte.

Conforme o exposto, a literatura consultada reforça a importância de estimação de parâmetros genéticos para população e condições específicas.

\subsubsection{Taxa reprodutiva}

A obtenção de parâmetros genéticos para características reprodutivas tem sido dificultada pelo fato da fertilidade ser considerada, em geral, propriedade dos pais (Bernier et al., 1951), enquanto a eclodibilidade é um caráter mais complexo, composto da viabilidade do embrião e do ambiente interno do ovo (efeitos maternos genéticos e ambientais), fornecidos pelas características genéticas e fenotípicas da galinha (Warren, 1927). De acordo com Abplanalp \& Kosin (1953), essas características que influenciam a viabilidade embrionária têm componentes hereditários. Assim, a produção de pintos, além de ser função da fertilidade dos reprodutores é uma característica geneticamente dependente do embrião e dos genótipos da galinha que produziu o ovo e do galo com a qual a galinha foi acasalada. 


\subsubsection{Repetibilidade e herdabilidade}

Crittenden \& Bohren (1961), pesquisando a influência dos efeitos genéticos e ambientais sobre a eclodibilidade em "White Leghorns", obtiveram repetibilidade igual a 0,29 ao final do período de nascimento dos pintos e sugeriram que devido ao baixo valor obtido, esse caráter deverá ser estudado utilizando-se várias incubações.

Sousa \& Custódio (1977), analisando características reprodutivas de três populações de galinhas para corte do Departamento de Genética da ESALQ, inseminadas com mistura de sêmen, encontraram as seguintes repetibilidades: 0,09 a 0,20 para fertilidade, 0,10 a 0,17 para eclodibilidade e 0,16 para nascimento. Como esses valores representam o limite superior da herdabilidade, os autores concluíram que tais caracteres possuem baixa herdabilidade. Zaborowsky \& Custódio (1978), avaliando ganhos genéticos para caracteres reprodutivos em duas populações de galinhas para corte do Departamento de Genética da ESALQ, inseminadas com mistura de sêmen, relataram as seguintes repetibilidades: 0,13 a 0,20 para fertilidade, 0,06 a 0,10 para eclodibilidade e 0,12 a 0,16 para nascimento; tendo sido as análises de variância obtidas com as médias das incubações, os autores indicaram que esses valores foram subestimados.

Ledur et al., (1994) determinando parâmetros genéticos e fenotípicos de características reprodutivas em galinhas para corte de duas linhas de fêmea em desenvolvimento no CNPSA/EMBRAPA, obtiveram as seguintes estimativas de herdabilidade: 0,23 a 0,50 para fertilidade e 0,06 a 0,13 para eclodibilidade.

Savino (1996), pesquisando a influência de métodos de controle da micoplasmose sobre estimativas de parâmetros genéticos para taxa reprodutiva de galinhas para corte de 12 linhagens obtidas na ESALQ/USP, determinou os seguintes valores máximos para as estimativas de repetibilidade: 0,203 para fertilidade, 0,228 para eclodibilidade e 0,236 para nascimento; o autor concluiu que os métodos de 
controle (vacinação de reprodutoras e/ou tratamento térmico dos ovos) da micoplasmose influenciaram negativamente as magnitudes dessas estimativas.

\subsubsection{Correlações genéticas, fenotípicas e ambientais}

Correlações genéticas, fenotípicas e ambientais entre características relacionadas à eficiência reprodutiva, tais como fertilidade, eclodibilidade e nascimento vem sendo analisadas por diversos autores. As principais estimativas obtidas encontram-se na Tabela 1.

Tabela 1. Correlações genéticas, fenotípicas e ambientais entre características reprodutivas encontradas na literatura.

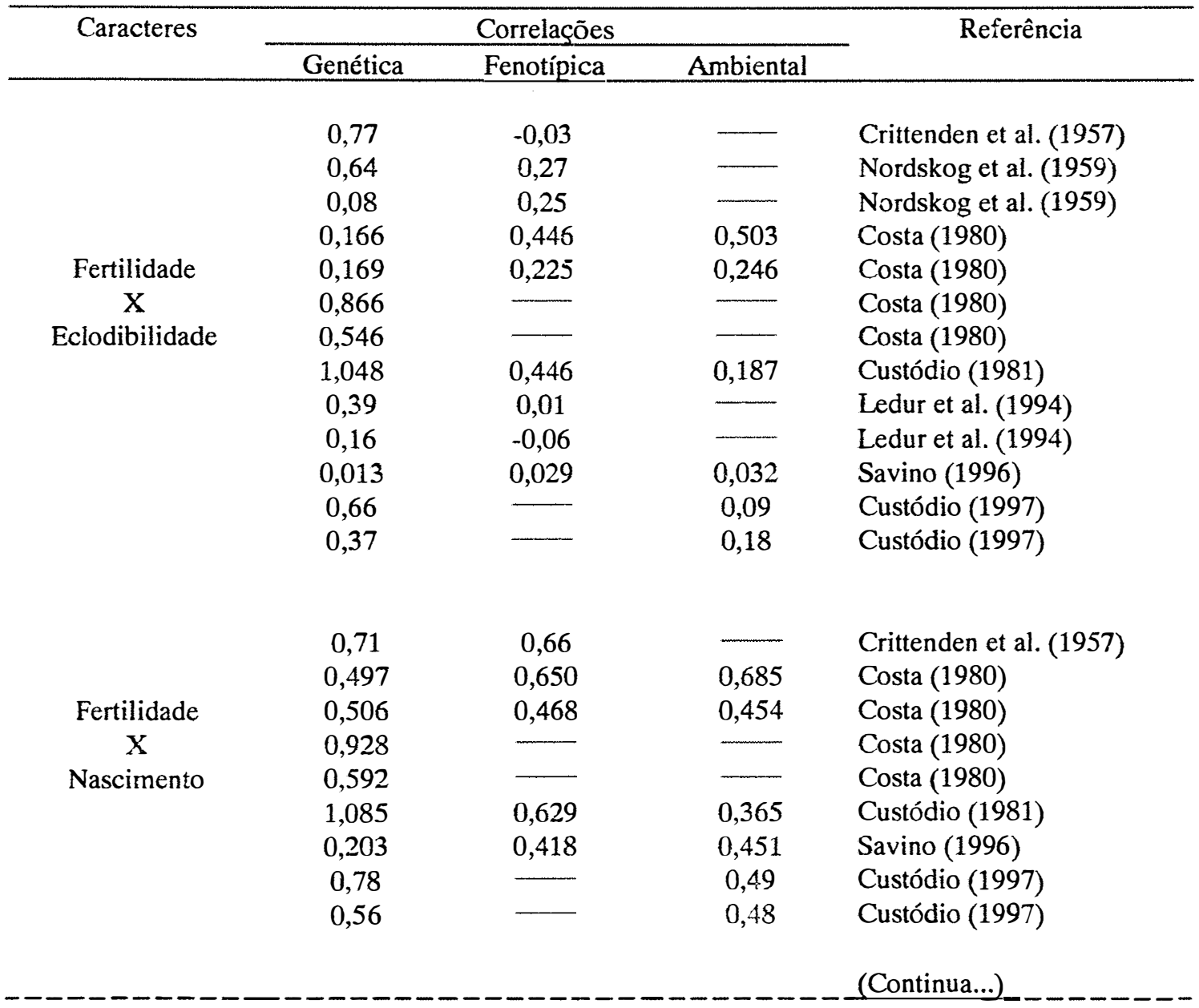


Tabela 1. Correlações genéticas, fenotípicas e ambientais entre características reprodutivas encontradas na literatura.

\begin{tabular}{ccccl}
\hline \multirow{2}{*}{ Caracteres } & \multicolumn{3}{c}{ Correlaçōes } & \multicolumn{1}{c}{ Referência } \\
\cline { 2 - 4 } & Genética & Fenotípica & Ambiental & \\
\hline (...C Continuaçāo) & 1,21 & 0,79 & - & Crittenden et al. (1957) \\
& 0,903 & 0,874 & 0,870 & Costa (1980) \\
Eclodibilidade & 0,970 & 0,880 & 0,848 & Costa (1980) \\
X & 0,952 & - & - & Costa (1980) \\
Nascimento & 0,994 & - & - & Costa (1980) \\
& 0,970 & 0,923 & 0,915 & Custódio (1981) \\
& 0,974 & 0,884 & 0,864 & Savino (1996) \\
& 0,98 & - & 0,89 & Custódio (1997) \\
& 0,97 & - & 0,93 & Custódio (1997) \\
\hline
\end{tabular}

Crittenden et al. (1957), analisando dados sobre fertilidade, eclodibilidade e nascimento de um plantel comercial de "New Hampshires", obtiveram correlações genéticas variando de 0,71 a 1,21 entre essas características (Tabela 1). As estimativas foram obtidas pela análise da variância e da covariância (Hazel et al., 1943) ou pela regressão intra-macho das mães sobre as filhas (Hazel, 1943). Devido a tendência observada das estimativas serem positivas, os autores sugeriram a existência de relações genéticas positivas entre as características em questão. As correlações fenotípicas fertilidade vs. nascimento e eclodibilidade vs. nascimento foram altas, uma vez que a fertilidade e a eclodibilidade determinam completamente o nascimento.

Costa (1980) realizou dois experimentos para avaliação de parâmetros genéticos e fenotípicos para caracteres reprodutivos em três populações de galinhas para corte do Departamento de Genética da ESALQ/USP. Obteve, a partir de componentes de variância e covariância entre galos e galinhas, estimativas de correlações genéticas, fenotípicas e ambientais entre fertilidade, eclodibilidade e nascimento (Tabela 1). As estimativas das correlações genéticas obtidas através de componentes de fêmeas apresentaram valores mais elevados devido aos efeitos genéticos de dominância e aos efeitos ambientais permanentes (maternos) associados 
às mesmas. Ficou evidenciado alto grau de associação entre eclodibilidade e nascimento.

Custódio (1981), apresentou uma ampla revisão da análise de variabilidade para características reprodutivas, inclusive de populações de galinhas para corte pertencentes ao Departamento de Genética da ESALQ/USP. Estimando correlações genéticas, fenotípicas e ambientais entre as características fertilidade, eclodibilidade e nascimento (Tabela 1), o autor concluiu que os caracteres fertilidade e eclodibilidade parecem ser praticamente idênticos, configurando-se os mesmos como diferentes medidas da viabilidade embriônica no período anterior e posterior ao $18^{\circ}$ dia de incubação. Concluiu também, que a eclodibilidade e o nascimento são características mais igualmente influenciadas pelos mesmos fatores ambientais, sendo fertilidade e eclodibilidade mais independentes.

Ledur et al. (1994) estimando parâmetros genéticos e fenotípicos para características reprodutivas em duas linhas de fêmea de galinhas para corte em desenvolvimento no CNPSA/EMBRAPA, obtiveram correlações genéticas médias e baixas e correlações fenotípicas nulas entre os caracteres fertilidade e eclodibilidade (Tabela 1). Savino (1996) obteve correlações genéticas praticamente nulas entre as características fertilidade e eclodibilidade de 12 linhagens de galinhas para corte desenvolvidas na ESALQ/USP (Tabela 1). Com relação aos caracteres eclodibilidade e nascimento, as elevadas correlações genéticas, fenotípicas e ambientais obtidas confirmaram forte associação positiva entre os mesmos.

Custódio (1997) estudando a herança de caracteres reprodutivos e ambiência, em três populações de galinhas para corte do Setor de Aves do Departamento de Genética da ESALQ/USP, relatou correlações genéticas e ambientais entre as características fertilidade, eclodibilidade e nascimento (Tabela 1). Como todos os caracteres reprodutivos mostraram-se geneticamente correlacionados entre si, o autor concluiu que poderiam se esperar respostas genéticas correlacionadas com seleção 
para qualquer um deles. As características eclodibilidade e nascimento seriam praticamente idênticas geneticamente, dada a alta correlação genética obtida entre elas, sendo elevada também a correlação ambiental. Já as correlações genéticas e ambientais obtidas entre fertilidade e nascimento foram de médio porte, de modo que tanto o melhoramento genético como o ambiental poderiam ser transmitidos em parte de um para o outro caráter.

\subsection{Variabilidade genética e "DNA fingerprinting"}

A importância da manutenção da variabilidade genética nas espécies de animais domésticos vem sendo muito difundida nos últimos anos (Crawford, 1990). Existe uma grande diversidade genética nos germoplasmas, e portanto, um imenso potencial no sentido de melhorar muitas das características economicamente importantes. Entretanto, programas de melhoramento encontram muitas vezes limitações, devido a inexistência de marcadores definidos associados aos caracteres mais relevantes e que possam ser utilizados para auxiliar a seleção. Se os materiais mais favoráveis pudessem ser rápida e eficientemente selecionados com base em marcadores moleculares que auxiliassem na predição dos comportamentos, teríamos ganhos de custos, tempo, esforço e espaço.

Vários marcadores de herança simples tem sido utilizados com sucesso ao

longo do tempo na seleção de caracteres geneticamente mais complexos ou cuja avaliação seja difícil, entre eles: caracteres morfológicos de herança monogênica, isoenzimas (Guse et al., 1988; Tanksley et al., 1981), proteínas e mais recentemente, os polimorfismos de DNA.

As análises de polimorfismos de DNA através da avaliação de fragmentos de restrição ou de outras técnicas, vêm se tornando poderosa ferramenta para a avaliação de diversidade genética, caracterização de germoplasmas, desenvolvimento de mapas genéticos detalhados, informações que incluídas em programas de melhoramento 
proporcionam novas possibilidades de seleção em vários níveis. Basicamente três propriedades tornam as análises de polimorfismos de DNA um eficiente sistema de marcação genética: a) o número de marcadores é quase ilimitado, sendo com eles possível saturar o genoma; b) os polimorfismos de DNA apresentam herdabilidade 1,0 pois são a própria representação do genoma, não sofrendo variações de expressão, penetrância, efeitos modificadores, e outros fatores; c) apresentam herança mendeliana simples e codominante, o que auxilia na identificação da condição do indivíduo (Evola et al., 1986; Helentjaris et al., 1985).

A análise de polimorfismos de restrição envolve a extração de DNA, produção de fragmentos por enzimas de restrição, separação eletroforética dos fragmentos e uso de sondas para a análise dos fragmentos por hibridização. Dois tipos de sondas tem sido aplicadas: sondas locus específicas, capazes de hibridizar em loci monocópia ou de baixo número de cópias, geralmente aplicadas em "restriction fragment length polymorphism" (RFLP) e sondas multi-loci, capazes de hibridizar em vários loci distribuídos pelo genoma (sequências repetitivas ou minisatélites) que caracterizam o DNA “fingerprinting” (DFP).

O genoma das aves pode ser intensivamente marcado pelo uso de sondas de DNA para locus múltiplos (Jeffreys et al., 1985a; Jeffreys, 1987; Haberfeld et al., 1991; Soller \& Beckemann, 1986). Alelos desses loci extremamente polimórficos são herdados como características mendelianas codominantes e podem ser detectados no mesmo tempo pelo uso de sondas especiais. Essas sondas especiais revelam bandas de DNA, cujos padrões são específicos para cada indivíduo e por isso são chamadas “DNA fingerprints"(DPF's), (Jeffreys et al., 1985b). Por serem extremamente específicos a cada indivíduo, os padrões de bandas de DFP's têm sido usados em casos onde a identificação individual absoluta é necessária. Além de aves (Hillel et al., 1989), DFP's tem sido encontrados nas mais diversas espécies de animais e plantas (Georges et al., 1988; Vassart, et al., 1987; Jeffreys \& Morton, 1987; Dallas, 
1988). Isso se deve a hibridação do DNA desses organismos eucariotos com as sequências de sondas multi-locus.

Em aves, uma única sonda multi-locus detecta cerca de 60 locus polimórficos (Hillel et al., 1989) e a ligação completa entre esses locus é muito rara. Por isso, a técnica que produz DFP's é considerada um poderoso instrumento para análises genéticas (Jeffreys \& Morton, 1987; Burke \& Bruford, 1987; Wetton et al., 1987).

A partir dos trabalhos de Jeffreys et al. (1985a,b), as análises de "DNA fingerprinting" (DFP) caracterizadas pela utilização de sondas capazes de hibridizar com regiões repetitivas hipervariáveis (HVRs), distribuídas no genoma de organismos eucariotos, têm se tornado um dos principais sistemas de identificação de indivíduos e/ou linhagens, com inúmeras aplicações no melhoramento. As bandas detectadas nas análises de DFP são extremamente polimórficas e mostram visualmente a variabilidade genética decorrente das variações nas sequências curtas de bases do DNA em todo o genoma. As bandas são, portanto, indicadoras de conjuntos de loci que representam posições ocupadas pelos genes ao longo dos cromossomos.

As análises de "DNA fingerprinting" são eficazes na avaliação de relações genéticas entre e dentro de populações (Kuhnlein et al., 1989; Dunnington et al., 1990; Siegel et al., 1992).

Kuhnlein et al. (1989) estudaram o emprego de "DNA fingerprinting" na determinação de distâncias genéticas entre linhagens de aves. Foram comparadas cinco linhagens, sendo quatro de postura derivadas de "White Leghorn" e uma de corte obtida de "New Hampshire". Os DNAs analisados foram obtidos de amostras de sangue de seis galinhas de cada linhagem. As distâncias genéticas calculadas entre pares de linhagens refletiram seus relacionamentos e origens; a linhagem de "New 
Hampshire" (galinhas para corte) apresentou maiores distâncias com as outras quatro linhagens de "White Leghorn" (galinhas para postura).

Dunnington et al. (1990) discutiram as diferenças observadas em padrões de "DNA fingerprinting" (DFP) entre duas linhagens de galinhas "White Plymouth Rocks", selecionadas em direções divergentes para peso corporal com oito semanas de idade. DNA's de 5, 10, 15 e 25 indivíduos foram misturados na base de um total de $10 \mu \mathrm{g}$. Os resultados indicaram que as misturas de DNA de indivíduos dentro de uma linhagem constituem um método efetivo para a comparação de DFP's entre grupos, podendo indicar a magnitude da variabilidade do DFP dentro das linhagens. Mistura de cinco amostras por pista foram suficientes para a obtenção de resultados representativos. Devido a dificuldade em comparar pistas de géis diferentes ou em lados opostos de um mesmo gel, a mistura de amostras de DNA constitue um meio efetivo para a obtenção de padrões gerais de DFP's.

Hillel et al. (1990) demonstraram que o padrão de "DNA fingerprinting" obtido nas análises de amostras compostas por misturas de sangue de perus de uma população específica, foi semelhante aquele verificado nas análises de DFP realizadas a partir de misturas de DNA de perus dessa população. Os autores concluiram que a mistura de amostras de sangue facilita a realização de análises de "DNA fingerprinting" principalmente para comparações simultâneas de várias populações. Haberfeld et al. (1992) estimando distâncias genéticas em cruzamentos de galinhas "White Plymouth Rocks" através do "DNA fingerprinting" também demonstraram que a realização dessas análises com misturas de amostras de sangue podem ser usadas com sucesso para estimar distâncias genéticas.

Dunnington et al. (1991) confirmaram a viabilidade do emprego das análises de "DNA fingerprinting" no estabelecimento de distâncias genéticas, utilizando populações de galinhas de origem conhecida e a técnica de mistura de DNA. Duas linhagens de "White Plymouth Rocks" selecionadas divergentemente para peso 
corporal à idade de 8 semanas, o F1 entre as mesmas, duas linhagens de "White Leghorns" selecionadas para alta ou baixa produção de anticorpos contra eritrócitos de carneiros, a idade aproximada de seis semanas e também o F1 entre estas foram utilizadas para obter DFP's, pela mistura de quantidades iguais de DNA de 9 a 15 aves de cada população. As maiores distâncias genéticas foram verificadas na comparação entre "White Plymouth Rocks" e "White Leghorns", distâncias intermediárias foram constatadas entre os pares de linhagens selecionados divergentemente e as menores distâncias genéticas, como era de se esperar, foram obtidas entre os F1's e as respectivas linhagens parentais.

Siegel et al. (1992) estudaram o relacionamento da galinha selvagem com a galinha doméstica com o auxílio do "DNA fingerprinting", obtido de análises de misturas de amostras de sangue de 3 a 5 aves, dentro de cada sexo, de 8 populações que incluiram: galinhas selvagens nativas, galinhas selvagens domesticadas, linhagens comerciais de poedeiras, linhagens comerciais de corte e populações controle. Os níveis de similaridade verificados nas análises indicaram que as linhagens comerciais são totalmente diferentes dos seus ancestrais selvagens; a distância genética entre as linhagens de corte foi menor que a verificada entre as linhagens de postura devido a maior herdabilidade das características de corte, fator condicionante da maior homogenidade entre as linhagens de corte.

Dunnington et al. (1994) em estudo da mesma natureza concluiram que a técnica do "DNA fingerprinting"estabeleceu um modo preciso para avaliar a diversidade genética e que as linhagens que dão origem a maioria das populações comerciais de melhoramento dos EUA ainda contem uma reserva considerável de diversidade genética. 


\section{MATERIAIS E MÉTODOS}

\subsection{Obtenção de parâmetros genéticos e fenotípicos}

A pesquisa foi realizada nas instalações experimentais do Setor de Aves do Departamento de Genética da Escola Superior de Agricultura "Luiz de Queiroz" da Universidade de São Paulo, em Piracicaba - SP, no período de Maio a Outubro de 1995. Os materiais experimentais utilizados foram aves de 12 linhagens de galinhas para corte, obtidas no Programa de Melhoramento Genético de Aves da ESALQ/USP (I1, I2, I3, P1, P2, P3, E1, E2, E3, G1, G2 e G3), sendo denominadas por I as linhagens macho da linha de macho, por $\mathrm{P}$ as de fêmeas da linha de macho, por $\mathrm{E}$ as de macho da linha fêmea e por $G$ as de fêmea da linha de fêmea. Os números 1,2 e 3 indicam diferentes épocas de obtenção: as linhagens (IPEG)1 foram obtidas em 1981, as (IPEG)2 em 1982 e as (IPEG)3 em 1984. Todas as linhagens são provenientes de avós, matrizes e híbridos comerciais. Desde a sua obtenção, as linhagens vem sendo melhoradas para taxa de crescimento e características reprodutivas utilizando-se seleção massal ou seja, seleção fenotípica individual das progênies obtidas de cruzamentos entre machos e fêmeas da mesma linhagem dentro de cada geração. 


\subsection{1 - Análises da taxa de crescimento}

\subsubsection{1 - Avaliações do peso corporal}

Com o objetivo de se avaliar o estágio de desenvolvimento do peso corporal das linhagens, foram pesadas individualmente ao completarem 28 dias de idade, todas as aves originadas em 16 incubações semanais consecutivas. A título de comparação foram avaliadas também as aves provenientes de ovos férteis produzidos por matrizes comerciais; os mesmos foram obtidos diretamente de incubatório comercial e incubados semanalmente junto com os ovos das linhagens experimentais.

Após serem retirados da máquina de eclosão, os pintos passaram por um processo de marcação através de corte e cauterização das falanges de dedos, para possibilitar a posterior identificação de sua origem. Ainda no incubatório, os pintos receberam vacinação contra a doença de Marek.

Os pintos foram alojados em galpões experimentais de $10 \times 25 \mathrm{~m}$ sem separação de sexo e linhagem, com uma lotação de 10 aves $/ \mathrm{m}^{2}$. Na primeira semana foram utilizadas campânulas elétricas (1000 Watts) para aquecimento das aves na proporção de 1 : 500 pintos. Até o quarto dia foram utilizados bebedouros tipo pressão (1 : 100 pintos), os quais eram lavados diariamente quando do fornecimento de água às aves. A partir do quinto dia, a água passou a ser fornecida em bebedouros do tipo pendular na proporção de $1: 80$ aves. No sétimo dia de idade as aves receberam vacinação contra as doenças de New Castle (amostra Lasota) e Gumboro na água de bebida.

Nos primeiros quatro dias a ração foi fornecida em comedouros tipo bandeja (1 : 100 pintos); a partir do quinto dia, esses comedouros foram substituídos por comedouros tubulares empregados na proporção de $1: 40$ aves. A ração foi distribuída manualmente, com quantidade suficiente de modo a fornecer ração a 
vontade às aves. Na Tabela 2 encontram-se os tipos de ração utilizados, porcentagens dos ingredientes e composição bromatológica das mesmas.

Tabela 2. Composição das rações utilizadas no período de avaliação do peso corporal.

\begin{tabular}{lcc}
\hline \multicolumn{1}{c}{ Ingredientes } & $\begin{array}{c}\text { Inicial } \\
(0-21 \text { dias })\end{array}$ & $\begin{array}{c}\text { Crescimento } \\
(22-28 \text { dias }) \\
\%\end{array}$ \\
\hline Milho & 63,913 & 69,463 \\
Farinha de Carne $(38 \%)$ & 5,200 & 4,500 \\
Farelo de Soja $(46 \%)$ & 29,800 & 24,800 \\
Calcário & 0,200 & 0,400 \\
Sal & 0,300 & 0,300 \\
Premix de Vitaminas e Minerais & 0,260 & 0,200 \\
Cloreto de Colina & 0,080 & 0,060 \\
Sulfato de Cobre & 0,040 & 0,040 \\
Coccidicida & 0,050 & 0,100 \\
DL Metiolina (98\%) & 0,155 & 0,135 \\
Violeta Genciana & 0,002 & 0,002 \\
\hline-3 Proteína Bruta (\%) & 21,00 & 19,00 \\
Energia Metabolizável $(\mathrm{Kcal} / \mathrm{Kg})$ & 3.000 & 3.150 \\
\hline
\end{tabular}

As aves receberam iluminação contínua 24 horas por dia, durante todo o período experimental. De dia a iluminação do interior dos galpões foi natural e à noite foi proporcionada por lâmpadas incandescentes (60 Watts, na proporção de $1: 500 \mathrm{~m}^{2}$ de área) que permaneceram ligadas do pôr ao nascer do sol. Todas as 5658 aves provenientes das 16 incubações semanais consecutivas foram avaliadas com relação ao peso corporal, aos 28 dias de idade, através de pesagem individual em balança tipo dinamômetro, com capacidade até $5 \mathrm{Kg}$ e precisão de $20 \mathrm{~g}$. Juntamente com a pesagem foi feita também a identificação fenotípica do sexo de cada ave, assim como, a determinação de sua origem através da leitura do código do corte de dedos. Os números de aves avaliados em cada incubação são apresentados no Apêndice.

As aves de cada linhagem (L) e sexo (S) avaliadas nas 16 incubações (I) constituíram um experimento fatorial em blocos casualizados, com 13 tratamentos 
(linhagens), 16 repetições (incubações) e 2 blocos (sexos). O modelo matemático correspondente foi:

$$
\begin{aligned}
& Y_{i j k l}=u+L_{i}+S_{j}+I_{k}+(L x I)_{i k}+e_{i j k l} \\
& \text { onde, } \\
& \mathrm{Y}_{\mathrm{ijkl}}=\text { Peso corporal aos } 28 \text { dias de idade correspondente a ave da linhagem } \\
& \text { i, sexo j, e incubação k; } \\
& \mathrm{u}=\text { média geral; } \\
& \mathrm{L}_{\mathrm{i}}=\text { efeito da linhagem } \mathrm{i} \text {; } \\
& S_{j}=\text { efeito do sexo } j \text {; } \\
& \mathrm{I}_{\mathrm{k}}=\text { efeito da incubação } \mathrm{k} \text {; } \\
& (\mathrm{Lx} \mathrm{I})_{\mathrm{ik}}=\text { efeito da interação da linhagem i com a incubação } \mathrm{k} \text {; } \\
& \mathrm{e}_{\mathrm{ijkl}}=\text { erro aleatório; }
\end{aligned}
$$

A análise de variância dos pesos corporais aos 28 dias de idade, realizada conforme Gomes (1982), foi processada pelo programa de computação SAS(1985) no procedimento GLM (General Linear Models), em função do desbalanceamento dos dados, com o seguinte modelo:

\begin{tabular}{lc}
\hline Fontes de Variação & G.L. \\
\hline Linhagem (L) & $l-1$ \\
Incubação (I) & $\mathrm{i}-1$ \\
Sexo (S) & $\mathrm{S}-1$ \\
LX I & $(l-1)(\mathrm{i}-1)$ \\
Resíduo & $\mathrm{t}-\mathrm{N}$ \\
\hline
\end{tabular}




$$
\begin{aligned}
& \text { onde, } \\
& l=\text { número de linhagens; } \\
& \mathrm{i}=\text { número de incubações; } \\
& \mathrm{s}=\text { número de sexos; } \\
& \mathrm{t} \text { = número total de G.L.; } \\
& \mathrm{N}=\text { somatória de G.L. de todas as fontes de variação, exceto o resíduo. }
\end{aligned}
$$

As análises de comparações de médias (least - squares) foram realizadas através do teste " $\mathrm{T}$ " como implementado no procedimento GLM do SAS. Empregaram-se contrastes para a comparação entre as médias globais dos materiais experimentais por grupo, ou seja, para a comparação entre as médias dos materiais experimentais (IPEG)1, (IPEG)2 e (IPEG)3 e também entre estes e o material comercial.

\subsubsection{2 - Obtenção de repetibilidades}

Com o objetivo de se determinar a magnitude de parâmetros genéticos, especificamente estimativas de repetibilidade para o peso corporal, realizou-se o seguinte experimento: uma amostra casualizada de 526 aves, de ambos os sexos, das 12 linhagens experimentais envolvidas na pesquisa, foi obtida no momento da avaliação do peso corporal aos 28 dias de idade, da $1^{\underline{\underline{a}}}, 3^{\underline{\underline{a}}}$ e $5^{\underline{\underline{a}}}$ incubação, da série de 16 incubações semanais envolvidas no estudo do item anterior; as aves que fizeram parte da referida amostragem foram identificadas individualmente através da colocação de anéis numerados na membrana de uma das asas.

Essas aves continuaram recebendo as mesmas condições de alimentação e manejo (anteriormente descritas) até completarem 35 dias de idade, quando foram novamente pesadas individualmente. Os pesos corporais foram obtidos conforme 
detalhado no item anterior, com a inclusão da informação relativa ao número do anel de cada ave avaliada. Deste modo, foram registrados 1052 pesos individuais relativos às 526 aves amostradas, aos 28 e 35 dias de idade, portanto, as estimativas de repetibilidade do peso corporal obtidas neste experimento referem-se ao período de 28 a 35 dias de idade. Os números de aves de cada uma das 12 linhagens experimentais envolvidas neste estudo encontram-se detalhados no Apêndice.

Para a realização das análises estatísticas, adotou-se o seguinte esquema de transformação dos dados obtidos em cada pesagem (Lasley, 1978):

$$
\text { Peso Relativo }=\frac{\text { Peso Real }}{\text { Peso Médio }} \times 100
$$

onde, Peso Relativo refere-se ao peso corporal individual transformado, Peso Real equivale ao peso corporal individual registrado na pesagem e Peso Médio corresponde ao valor médio verificado para Peso Real. Essa transformação promoveu a normalização da distribuição dos dados que originalmente apresentaram-se com grande variação, em decorrência do intervalo de sete dias estabelecido entre as duas pesagens individuais das aves.

As estimativas de repetibilidade foram obtidas pelo programa de computação "LSMLMW and MIXMDL PC - 2 version" (Mixed model least - squares and maximum likelihood) de Harvey (1990).

O modelo estatístico envolveu efeitos considerados fixos (linhagens) e efeitos aleatórios (aves dentro de linhagem) sendo apresentado a seguir:

$$
\begin{aligned}
& Y_{i j k}=u+L_{i}+a_{j}: L_{i}+e_{i j k} \\
& \text { onde, } \\
& Y_{i j k}=\text { Peso corporal referente à ave } j \text { da linhagem } i ; \\
& u=\text { média geral; }
\end{aligned}
$$




$$
\begin{aligned}
& L_{i}=\text { efeito da linhagem } i \\
& a_{j}: L_{i}=\text { efeito da ave } j \text { dentro da linhagem } i \\
& e_{i j k}=\text { erro aleatório. }
\end{aligned}
$$

\subsubsection{Análises dos desempenhos reprodutivos}

Com a finalidade de se obterem parâmetros genéticos e fenotípicos para características associadas ao desempenho reprodutivo das 12 linhagens, foi realizado um estudo com 1908 observações individuais de características reprodutivas de aves reproduzidas durante 16 semanas consecutivas.

Essas aves eram provenientes de cruzamentos de reprodutores da mesma linhagem, acasalados através de inseminação artificial com mistura do sêmen coletado individualmente. Do nascimento até a idade de 35 dias as aves foram submetidas a condições experimentais idênticas as descritas no item 3.1.1.1. No $35^{\circ}$ dia as mesmas foram identificadas individualmente através da colocação de anéis numerados na membrana de uma das asas.

Após o anelamento, as aves foram alojadas em gaiolas individuais de arame galvanizado com as dimensões de $25 \mathrm{~cm}$ (frente) X $35 \mathrm{~cm}$ (fundo) X $30 \mathrm{~cm}$ (altura). As gaiolas foram dotadas de comedouros tipo calha e bebedouros automáticos tipo "nipple". As aves foram arraçoadas diariamente e submetidas a programa específico de luz. Na Tabela 3 são apresentados os esquemas de alimentação e iluminação adotados. A composição das rações utilizadas encontra-se na Tabela 4. 
Tabela 3. Esquemas de arraçoamento e iluminação adotados no manejo das aves utilizadas na avaliação do desempenho reprodutivo.

\begin{tabular}{cccc}
\hline $\begin{array}{c}\text { Idade } \\
\text { (Semanas) }\end{array}$ & $\begin{array}{c}\text { Tipo de } \\
\text { Ração }\end{array}$ & $\begin{array}{c}\text { Arraçoamento } \\
\text { (gramas/ave/dia) }\end{array}$ & $\begin{array}{c}\text { Iluminação } \\
\mathrm{n}^{\mathbf{o}} \text { horas luz/dia }\end{array}$ \\
\hline $5-18$ & Recria & restrição alimentar(*) & natural \\
19 & Reprodução & 95 & 15 \\
20 & Reprodução & 100 & 16 \\
21 & Reprodução & 109 & 16 \\
22 & Reprodução & 118 & 16 \\
23 & Reprodução & 125 & 16 \\
24 & Reprodução & 136 & 16 \\
25 & Reprodução & 145 & 16 \\
26 & Reprodução & 152 & 16 \\
27 & Reprodução & 161 & 16 \\
28 & Reprodução & 165 & 16 \\
29 & Reprodução & 166 & 16 \\
30 & Reprodução & 167 & 16,5 \\
31 em diante & Reprodução & 167 & 17 \\
\hline
\end{tabular}

$\left(^{*}\right)$ quantidade ajustada de acordo com a evolução do peso corporal

Tabela 4. Composição das rações de recria e reprodução utilizadas.

\begin{tabular}{lcc}
\hline \multicolumn{1}{c}{ Ingredientes } & Recria (\%) & Reprodução (\%) \\
\hline Milho & 62,960 & 67,700 \\
Farinha de Carne (38\%) & 2,600 & 3,200 \\
Farelo de Soja (46\%) & 11,400 & 19,200 \\
Farelo de Trigo & 21,000 & 3,000 \\
Calcário & 1,320 & 6,170 \\
Sal & 0,220 & 0,230 \\
Premix de Vitaminas e Minerais_____-_-_-_-_-_- & 0,500 & 0,500 \\
\hline Proteína Bruta(\%) & 16,00 & 17,00 \\
Energia Metabolizável (Kcal/Kg) & 2.800 & 2.900 \\
Ca (\%) & 1,00 & 3,30 \\
P(\%) & 0,40 & 0,40 \\
\hline
\end{tabular}

A reprodução das aves foi realizada no período de 31 a 47 semanas de idade média. Os cruzamentos foram feitos utilizando-se machos e fêmeas da mesma linhagem, com o auxílio da inseminação artificial, praticada duas vezes por semana com mistura do sêmen coletedo individualmente. Os ovos foram coletados quatro 
vezes por dia, identificados manualmente em relação às galinhas que os produziram e encaminhados ao incubatório. No incubatório foram fumigados com formaldeído a $40 \%$ durante 20 minutos e estocados em câmara fria por até sete dias à $16^{\circ} \mathrm{C}$ e $65 \%$ de umidade relativa.

Após esse período de estocagem os ovos foram retirados da câmara fria, submetidos a um pré-aquecimento em câmara apropriada e a seguir, foram incubados de maneira convencional. No $18^{\underline{0}}$ dia de incubação todos os ovos foram transferidos da incubadora para a câmara de eclosão, onde foram acondicionados em cestas de pedigree. Os pintos foram retirados da câmara de eclosão do $21^{\circ}$ ao $22^{\circ}$ dia de incubação. Após os nascimentos foram obtidos os dados para cálculo dos parâmetros reprodutivos. O número de ovos férteis foi obtido através da abertura dos ovos do resíduo da incubação, com a observação de embriões não nascidos sendo somada ao número de pintos nascidos.

As características reprodutivas avaliadas foram: (NOI) número de ovos incubados, (NOF) número de ovos férteis, (NPTS) número de pintos nascidos, (FERT) Fertilidade $\%=(\mathrm{NOF} / \mathrm{NOI}) \mathrm{X} 100,($ ECLOD) Eclodibilidade $\%=$ (NPTS/NOF) X 100 e (NASC) Nascimento $\%=($ NPTS/NOI) X 100. Os números de observações avaliadas em cada uma das 12 linhagens envolvidas nesta pesquisa, assim como, os valores das características reprodutivas correspondentes a essas observações encontram-se de forma detalhada no Apêndice.

A análise de variância das características reprodutivas estudadas foi realizada através do programa de computação SAS (1985) no procedimento GLM (General Linear Models), em função do desbalanceamento dos dados. As comparações entre médias (least - squares) foram feitas pelo teste " $T$ ". As estimativas de herdabilidade $e$ as correlações genéticas, fenotípicas e ambientais foram obtidas pelo programa de computação "LSMLMW and MIXMDL PC - 2 version" (Mixed model least - squares and maximum likelihood) de Harvey (1990). 
O modelo estatístico envolveu efeitos fixos (linhagens e incubações) e efeitos aleatórios (galinhas dentro de linhagens) sendo apresentado a seguir:

$Y_{i j k}=u+L_{i}+g_{j}: L_{i}+I_{k}+(L X I)_{i k}+e_{i j k}$

em que,

$\mathrm{Y}_{\mathrm{ijk}}=$ valor da característica reprodutiva referente à galinha $\mathrm{j}$ da linhagem $\mathrm{i}$, obtida na incubação k;

$\mathrm{u}=$ média geral;

$\mathrm{L}_{\mathrm{i}}=$ efeito da linhagem $\mathrm{i}$;

$g_{j}: L_{i}=$ efeito da galinha $j$ dentro da linhagem $i$

$\mathrm{I}_{\mathrm{k}}=$ efeito da incubação $\mathrm{k}$;

$(\mathrm{L} \mathrm{x} \mathrm{I})_{\mathrm{ik}}=$ efeito da interação da linhagem i com a incubação $\mathrm{k}$;

$e_{i j k}=$ efeito da interação da galinha $\mathrm{j}$ com a incubação $\mathrm{k}$ dentro da linhagem $\mathrm{i}$.

No quadro a seguir são apresentadas as fontes de variação, graus de liberdade (G.L) e as esperanças dos quadrados médios [E (Q. M.)] referentes ao modelo utilizado:

\begin{tabular}{lcr}
\hline Fontes de Variação & G.L. & \multicolumn{1}{c}{$\mathrm{E}(\mathrm{Q} . \mathrm{M})$} \\
\hline Linhagens (L) & $l-1$ & $\sigma_{\mathrm{e}}^{2}+\mathrm{k}_{3} \sigma_{\mathrm{g}: \mathrm{L}}^{2}+\mathrm{k}_{4} \mathrm{~K}_{\mathrm{L}}^{2}$ \\
Galinhas : L & $\mathrm{g}-1$ & $\sigma_{\mathrm{e}}^{2}+\mathrm{k}_{2} \sigma_{\mathrm{g}: \mathrm{L}}^{2}$ \\
Incubações (I) & $\mathrm{i}-1$ & $\sigma_{\mathrm{e}}^{2}+\mathrm{k}_{1} \mathrm{~K}_{1}^{2}$ \\
L X I & $(l-1)(\mathrm{i}-1)$ & $\sigma_{\mathrm{e}}^{2}+\mathrm{k} \mathrm{K} \mathrm{K}_{\mathrm{LI}}$ \\
Resíduo & $\mathrm{t}-\mathrm{N}$ & $\sigma_{\mathrm{e}}^{2}$ \\
\hline
\end{tabular}

onde,

$l=$ número de linhagens; 


$$
\begin{aligned}
& \mathrm{g}=\text { número de galinhas; } \\
& \mathrm{i}=\text { número de incubações; } \\
& \mathrm{t}=\text { número total de G.L.; } \\
& \mathrm{N}=\text { soma de G.L. das fontes de variação, exceto o resíduo; } \\
& \sigma_{\mathrm{e}}^{2}=\text { variância devida à interação de galinhas com incubações dentro de } \\
& \mathrm{k}=\mathrm{g} ; \mathrm{k}_{1}=\text { linhagens; } ; \mathrm{k}_{2}=\mathrm{k}_{3}=\mathrm{i} ; \mathrm{k}_{4}=\text { g.i ; } \\
& \mathrm{\sigma}_{\mathrm{g}}^{2} \text { : } \mathrm{L}=\text { variância devida a diferenças entre galinhas dentro de linhagens. } \\
& \text { 3.2. Análises da variabilidade genética através do “DNA fingerprinting” }
\end{aligned}
$$

\subsection{Análises da variabilidade genética através do "DNA fingerprinting"}

Com o objetivo de avaliar a variabilidade genética das 12 linhagens experimentais envolvidas nesta pesquisa, realizaram-se também, análises laboratoriais pela técnica do "DNA fingerprinting" (DFP) que proporcionaram a obtenção de polimorfismos de DNA, com os quais se obtiveram índices de similaridade equivalentes as distâncias genéticas existentes entre as linhagens estudadas. A descrição detalhada da metodologia envolvida nesse estudo é apresentada a seguir. No Apêndice estão relacionadas as composições das soluções utilizadas.

\subsubsection{Extração de DNA das aves}

O DNA foi extraído de amostras de sangue coletadas das aves através do procedimento adaptado por Hillel ${ }^{1}$. Da veia braquial de cinco galinhas de cada uma das 12 linhagens experimentais foi coletada uma amostra de $1 \mathrm{ml}$ de sangue (por ave) com uso de seringa descartável. Essas cinco amostras de cada linhagem foram

\footnotetext{
${ }^{1}$ Hillel, J. (Department of Genetics, Faculty of Agriculture, The Hebrew University of Jerusalem, Rehovot, Israel). Comunicação pessoal, 1991.
} 
transferidas para um vidro esterilizado contendo anticoagulante (EDTA a $2 \%$ na proporção de $0,05 \mathrm{ml}$ de solução/ml de sangue), obtendo-se assim uma mistura representativa de cada linhagem. Em seguida o material foi colocado em freezer a -20 ${ }^{\circ} \mathrm{C}$ para congelamento e estocagem.

Um volume de $50 \mu \mathrm{l}$ de sangue descongelado $\left(37^{\circ} \mathrm{C}\right.$ em banho Maria) foi transferido para tubo "eppendorf" onde foram adicionados $500 \mu \mathrm{l}$ de SSC 10x (Citrato e Cloreto de sódio) e SDS 10\% (Sódio Dodecil Sulfato) até 1\% e depois misturados suavemente por 30 segundos. Adicionaram-se ainda nesse tubo $500 \mu \mathrm{lde}$ fenol/clorofórmio (1:1 em volume) e homogenizou-se a mistura com auxílio de pipetação. A seguir centrifugou-se o material por 5 minutos em microcentrífuga a $15000 \mathrm{rpm}$. Transferiu-se o sobrenadante para outro tubo, desprezando-se a interfase. Repetiu-se novamente essa extração com fenol/clorofórmio.

No sobrenadante separado após a segunda extração com fenol/clorofórmio adicionou-se etanol $100 \%$ na proporção de 2,5 vezes o volume do sobrenadante. Centrifugou-se por 5 minutos a $15000 \mathrm{rpm}$, descartou-se o sobrenadante e lavou-se o precipitado com $500 \mu \mathrm{l}$ de etanol $70 \%$. Dissolveu-se mais uma vez esse precipitado em $400 \mu \mathrm{l} \mathrm{H} \mathrm{H}_{2} \mathrm{O}$. Repetiu-se a precipitação com o etanol 100\% e a lavagem com etanol $70 \%$ do DNA precipitado. Secou-se o precipitado invertendo o tubo sobre papel de filtro e ao final da extração dissolveu-se o DNA em $150 \mu 1$ de tampão TE. O DNA extraído das amostras foi preservado nessa solução e estocado em freezer. A absorbância do DNA extraído das amostras foi medida em espectrofotômetro a 260 e $280 \mathrm{~nm}$ para verificar sua concentração e pureza. A integridade do DNA foi avaliada eletroforéticamente em gel de $0,8 \%$ de agarose em tampão TAE $1 \mathrm{x}$, em corrida de uma hora a $100 \mathrm{~V}$, utilizando-se $250 \mathrm{ng}$ de DNA por amostra. 


\subsubsection{Digestão do DNA e separação em gel}

Com base na quantificação anterior, $10 \mu \mathrm{g}$ de DNA de cada uma das 12 linhagens experimentais envolvidas na pesquisa, foram digeridos utilizando-se a enzima de restrição Hinf I, na proporção de 4 unidades da enzima por ug de DNA. Adicionaram-se ainda $2,5 \mathrm{mM}$ de espermídina e $30 \mu \mathrm{l}$ do tampão de enzima para um volume final de $300 \mu \mathrm{l}$. As amostras foram colocadas em estufa a $37^{\circ} \mathrm{C}$ por 12 horas. A digestão das amostras foi confirmada através de corrida eletroforética em gel de agarose $0,8 \%$ em tampão de corrida $(12,5 \mathrm{ml} \mathrm{TE} \mathrm{pH} \mathrm{8,0;12,5} \mathrm{ml} \mathrm{glicerol} \mathrm{;} 25 \mathrm{ng}$ bromofenol), por três horas a $80 \mathrm{~V} ; 500 \mathrm{ng}$ de cada digestão foram utilizadas em cada canaleta, e como padrão foi aplicado fago $\lambda$ cortado com Hind III.

Para precipitação do DNA de cada uma das digestões adicionaram-se 1/10 do volume de acetato de sódio 3M e 2,5 volumes de etanol absoluto. Em seguida o material foi colocado em freezer $-70{ }^{\circ} \mathrm{C}$ por 1 hora ; depois centrifugou-se por 15 minutos a $12000 \mathrm{rpm}$ e descartou-se o sobrenadante. O DNA precipitado foi então lavado com $500 \mu \mathrm{l}$ de etanol $70 \%$ e seco. A seguir o DNA foi ressuspendido em $20 \mu \mathrm{l}$ de TE.

O gel definitivo foi preparado com $0,8 \%$ de agarose em tampão TBE $1 x$. $O$ tamanho do gel foi de $19 \times 20 \mathrm{~cm}$, com 13 canaletas. Foram acrescentados $3 \mu \mathrm{lde}$ tampão stop/ficoll (10 ml TBE 10x ; 1,25 g ficoll $400 ; 0,01 \mathrm{~g}$ bromofenol) em cada amostra do DNA digerido que estava diluído em $20 \mu \mathrm{l}$ de TE. Como padrão de peso molecular foram colocados no gel, juntamente com as amostras, $2 \mu \mathrm{g}$ de $\lambda /$ Hind III. A corrida foi feita a $34 \mathrm{~V}$ por um período de 48 horas a temperatura ambiente, quando o padrão de $2 \mathrm{~Kb}$ atingiu o fim do gel. $\mathrm{O}$ gel foi colocado em solução de brometo de etídio $(0,5 \mu \mathrm{g} / \mathrm{ml})$ por 20 minutos sob agitação lenta e depois lavado em água destilada. 


\subsubsection{Transferência do DNA para membrana de nylon}

A imobilização do DNA em membrana de nylon foi realizada conforme protocolo descrito por Sambrook et al. (1989) com algumas modificações descritas a seguir. O DNA foi depurinado colocando-se o gel em $80 \mathrm{ml}$ de solução de depurinação $(0,25 \mathrm{M} \mathrm{HCl})$ por 16 minutos com agitação. A seguir foi lavado brevemente em água destilada e acrescentou-se $800 \mathrm{ml}$ da solução de desnaturação ( $0,5 \mathrm{M} \mathrm{NaOH} ; 1,5 \mathrm{M} \mathrm{NaCl})$, deixando-se o mesmo nessa solução por 30 minutos sob agitação. O gel foi então lavado com água destilada e a seguir acrescentou-se $800 \mathrm{ml}$ de solução de neutralização (0,5 M Tris pH 7,5;1,5 M NaCl ; 0,001 M EDTA), na qual o gel ficou por 30 minutos sob agitação. Depois transferiu-se o gel para solução SSC 20 vezes concentrado.

O DNA foi transferido para membrana de nylon por capilaridade, em sistema semelhante ao de Southern (1975), descrito a seguir. Inicialmente foi colocada uma plataforma dentro de um reservatório e sobre ela uma ponte de papel Whatman 3 MM (3 folhas cortadas de tamanho apropriado) saturada com solução de transferência (SSC 20x), sendo as bolhas retiradas com auxílio de bastão de vidro. O gel foi colocado invertido sobre essa ponte. Em volta do gel foi colocada fita de parafilme para evitar que o tampão de transferência fosse absorvido diretamente pelas toalhas de papel acima do gel. A membrana (Hybond $\mathrm{N}$ ) do tamanho do gel foi cortada e umedecida em água Milli - Q e em seguida transferida para solução de transferência; logo após foi colocada sobre o gel com cuidado para não formar bolhas. Foram colocadas 3 folhas de papel $3 \mathrm{MM}$ umedecidas em solução de transferência em cima da membrana, e uma pilha de papel de germinação de altura aproximada de $5 \mathrm{~cm}$ em cima das folhas $3 \mathrm{MM}$. Uma placa de acrílico foi colocada em cima da pilha de papel e, sobre esta um peso de aproximadamente $0,7 \mathrm{Kg}$. Na figura 1 é apresentado esquematicamente o sistema montado para a transferência. 


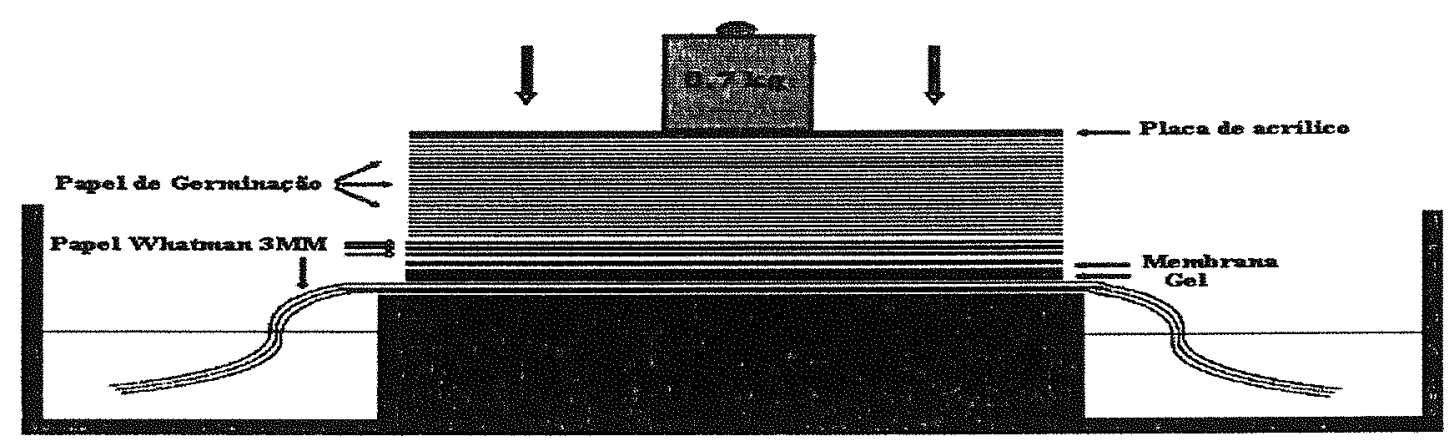

Figura 1. Representação esquemática do sistema montado para a transferência de DNA para membrana de nylon

O período de transferência foi de 24 horas. Após este período, a membrana foi marcada com lápis para posterior identificação das pistas. O canto da membrana foi cortado para marcar o início do gel. A seguir, a membrana foi removida e colocada imediatamente em solução de SSC $2 x$ com agitação branda por 2 minutos para remover os vestígios de agarose aderidos à membrana. A mesma foi colocada entre duas folhas de papel de germinação para poder secar. Depois de seca foi colocada em estufa a $80^{\circ} \mathrm{C}$ por duas horas. Após esta etapa a membrana foi conservada em local seco, à temperatura ambiente.

\subsubsection{Preparação da sonda}

Para a hibridização com o DNA das amostras transferido para a membrana foi utilizada a sonda R 18.1 desenvolvida no laboratório do Dr. Jossy Hillel (Department of Genetics, Faculty of Agriculture, The Hebrew University of Jerusalem, Rehovot/Israel). Essa sonda é do tipo multi - loci, constituindo-se de clone de minisatélite de origem bovina. A mesma apresenta peso molecular de $1 \mathrm{~Kb}$ contendo sequência longa repetitiva de 36 pb e sequências ricas em CA (Haberfeld \& Hillel, 1991). 
A sonda incorporada no plasmídeo pIBI 30 foi inicialmente plaqueada em meio de cultura LB sólido com ampicilina $(2 \mu \mathrm{I} / \mathrm{ml})$ e incubada a $37^{\circ} \mathrm{C}$ durante a noite. Em seguida, colônias isoladas crescidas nesse meio foram transferidas para 2 $\mathrm{ml}$ do meio de cultura LB líquido, com ampicilina $(2 \mu \mathrm{l} / \mathrm{ml})$ e submetidas a $37^{\circ} \mathrm{C}$ sob agitação de $250 \mathrm{rpm}$ durante a noite. As colônias multiplicadas nesse meio foram utilizadas para a extração do DNA plasmidial, de acordo com o protocolo de Sambrook et al. (1989).

Transferiu-se 1,5 $\mathrm{ml}$ dessa cultura para um eppendorf, sendo o mesmo centrifugado a $15.000 \mathrm{rpm}$ por dois minutos, após o que descartou-se o sobrenadante. O precipitado foi ressuspendido em $100 \mu \mathrm{l}$ de solução composta de glucose $50 \mathrm{mM}$, Tris $\mathrm{HCl} 25 \mathrm{mM} / \mathrm{pH}=8,0$ e EDTA $10 \mathrm{mM}$, com homogenização em vortex. Adicionaram-se $200 \mu \mathrm{l}$ de solução contendo $\mathrm{NaOH}$ 0,2 M e SDS $1 \%$ e misturou-se por inversão. A seguir adicionam-se $150 \mu \mathrm{l}$ de solução de acetato de potássio $3 \mathrm{M} / \mathrm{pH}$ $=4,8$ misturando-se também por inversão. Centrifugou-se por três minutos a 15.000 rpm e transferiram-se $400 \mu \mathrm{l}$ do sobrenadante para um eppendorf contendo $720 \mu \mathrm{l}$ de etanol absoluto. Misturou-se por inversão e centrifugou-se por um minuto a 15.000 rpm. Descartou-se o sobrenadante e lavou-se o precipitado com $600 \mu \mathrm{l}$ de etanol $70 \%$. Centrifugou-se novamente por dois minutos a $15.000 \mathrm{rpm}$ e descartou-se o etanol. O DNA precipitado foi seco em estufa a $37^{\circ} \mathrm{C}$ e ressuspendido em $200 \mu \mathrm{l}$ de TE.

A seguir efetuou-se a digestāo do DNA plasmidial contendo a sonda R 18.1 com as enzimas de restrição Eco RI e Hind III, utilizando-se $4 \mu$ la solução com o DNA ressuspendido e $1 \mu \mathrm{l}$ de cada enzima. Com o DNA plasmidial digerido promoveu-se a eletroforese em gel de agarose $1 \%$ com tampão TAE 1x. A banda contendo o inserto (sonda $R$ 18.1) foi identificada e retirada do gel através de corte com bisturi. Esse fragmento de agarose contendo a sonda foi colocado em um eppendorf com uma pequena perfuração na base e cobertura de lã de vidro sobre a mesma, tendo sido este tubo acoplado a outro eppendorf vazio. O conjunto de 
eppendorfs foi colocado em freezer a $-20^{\circ} \mathrm{C}$ por 20 minutos, sendo em seguida centrifugado por 10 minutos a $6.000 \mathrm{rpm}$. O líquido (tampão TAE) contendo o DNA da sonda passou pela lã de vidro e pelo furo do primeiro tubo, ficando retido no tubo inferior.

Adicionou-se nesse tubo $1 / 10$ do volume de acetato de sódio $3 \mathrm{M} / \mathrm{pH}=5,2$ e dois volumes de etanol absoluto, colocando-se a seguir o mesmo em freezer a $-20^{\circ}$ $\mathrm{C}$ por 30 minutos. Após esse período centrifugou-se o material por 15 minutos a $12.000 \mathrm{rpm}$ e descartou-se o etanol. Adicionaram-se $300 \mu \mathrm{l}$ de etanol $70 \%$ e misturouse por inversão. Centrifugou-se novamente por cinco minutos a $12.000 \mathrm{rpm}$, após o que descartou-se o etanol, preservando o precipitado no tubo. O DNA da sonda precipitado foi seco em estufa a $37^{\circ} \mathrm{C}$, ressuspendido em $20 \mu \mathrm{l}$ de TE e quantificado em gel de agarose $1 \%$ com os marcadores $\lambda$ HindIII / $\phi \times 174$ HaelII nas concentrações de 60 e 120 ng servindo como padrão.

Antes da hibridização a sonda foi marcada com fósforo $32\left(\left[\alpha-{ }^{32} \mathrm{P}\right] \mathrm{d}\right.$ CTP) através da enzima Klenow, de acordo com o método adaptado por Hillel ${ }^{2}$, descrito a seguir. Adicionaram-se $24 \mu \mathrm{l} \mathrm{H} \mathrm{H}_{2} \mathrm{O}$ em $1 \mu \mathrm{l}$ da sonda e denaturou-se por cinco minutos a $100{ }^{\circ} \mathrm{C}$ em banho. Em seguida colocou-se o material no gelo para não ocorrer a renaturação do DNA. A mistura de marcação do Kit Multi Prime foi retirada do freezer $-20^{\circ} \mathrm{C}$ e colocada no gelo. Adicionaram-se então ao tubo com a sonda $11 \mu \mathrm{l}$ da mistura de marcação, $4 \mu \mathrm{l}\left[\alpha-{ }^{32} \mathrm{P}\right]$ d CTP $(10 \mathrm{u} \mathrm{Ci} / \mathrm{ml})$ e $1 \mu \mathrm{l}$ da enzima Klenow (2U). Misturou-se suavemente o material por pipetação e deixou-se o material reagindo por três horas à temperatura ambiente.

\footnotetext{
${ }^{2}$ Hillel, J. (Department of Genetics, Faculty of Agriculture, The Hebrew University of Jerusalem, Rehovot, Israel). Comunicação pessoal, 1991.
} 


\subsubsection{Hibridização}

Inicialmente a membrana contendo o DNA das amostras foi pré - hibridizada com uma solução de hibridização contendo $\mathrm{Na}_{2} \mathrm{HPO}_{4}$ 0,263 M, SDS 7\%, EDTA 1 $\mathrm{mM}$ e BSA $1 \%$. Essa solução foi previamente aquecida a $65{ }^{\circ} \mathrm{C}$ sendo então transferidos $40 \mathrm{ml}$ para tubo de hibridização contendo a membrana. Esse tubo foi levado ao forno de hibridização onde a membrana ficou pré - hibridizando a $65^{\circ} \mathrm{C}$ por quatro horas.

Denaturou-se a sonda marcada através de aquecimento $\left(100{ }^{\circ} \mathrm{C}\right.$ por cinco minutos) e em seguida colocou-se a mesma em gelo. Transferiu-se $1 \mathrm{ml}$ da solução que estava no tubo de hibridização para o tubo que continha a sonda marcada, misturou-se através de pipetação, adicionou-se então a sonda no tubo de hibridização e deixou-se o material hibridizando no forno com rotação a $65^{\circ} \mathrm{C}$ durante à noite.

\subsubsection{Obtenção da autoradiografia}

Após o período da hibridização a membrana foi submetida a sucessivas lavagens com $\mathrm{Na}_{2} \mathrm{HPO}_{4}$ 0,263 $\mathrm{M}$ e SDS $1 \%$ (uma vez, por 20 minutos, a $65^{\circ} \mathrm{C}$ ), e ainda com SSC $2 x$ e SDS $0,1 \%$ (duas vezes, por 20 minutos, a $65^{\circ} \mathrm{C}$ ). Em seguida, a membrana foi envolvida em plástico de textura fina e colocada em cassete para autoradiografia junto com filme de raio X (Kodak - XOMAT XAR2). O cassete foi colocado em freezer $-70{ }^{\circ} \mathrm{C}$ por três dias. Ao término desse período de exposição, o cassete foi aberto e procedeu-se a revelação da autoradiografia da seguinte forma: a) colocou-se a mesma em solução de revelação (revelador GBX / Kodak) por três minutos; b) lavou-se em água corrente; c) colocou-se a autoradiografia em solução de fixação (fixador GBX / Kodak) por quatro minutos e d) lavou-se em água corrente para eliminar os resíduos da mesma. Após estas etapas a autoradiografia foi posta para secar. 


\subsubsection{Avaliação dos perfis}

Os perfis revelados na autoradiografia foram avaliados visualmente, levando-se em consideração as variações qualitativas (presença e ausência de bandas) e quantitativas (intensidade das bandas) em cada uma das amostras de DNA analisadas, relativas as linhagens experimentais em estudo.

Com base nesses resultados procedeu-se à determinação das relações de similaridade entre os materiais. Para tanto, os mesmos foram avaliados de acordo com Jeffreys \& Morton (1987) através do "bandsharing" (BS) ou índice de similaridade, que vem a ser a proporção de bandas em comum relativa ao total de bandas avaliadas nos perfis, na comparação entre dois materiais, ou seja:

$$
\mathrm{BS}=\frac{(\mathrm{Nab})}{(\mathrm{Na}+\mathrm{Nb}) / 2}
$$

onde, $\mathrm{BS}=$ nível de "bandsharing" entre 2 amostras, $\mathrm{Nab}=$ número de bandas presentes simultâneamente nas 2 amostras, $\mathrm{Na}=$ número de bandas presentes na amostra $\mathrm{A} \mathrm{e} \mathrm{Nb}=$ número de bandas presentes na amostra $\mathrm{B}$.

Os BS obtidos foram utilizados para a obtenção de dendograma, através do programa de computação NTSYS - pc (Numerical Taxonomy and Multivariate Analysis System) de Rohlf (1992) com o objetivo de se identificar entre as linhagens estudadas, as que apresentavam maior ou menor similaridade genética, de forma análoga ao realizado por Gentzbittel \& Nicolas (1991). 


\section{RESULTADOS E DISCUSSÃO}

\subsection{Análise da taxa de crescimento}

Os pesos corporais médios obtidos pela pesagem individual aos 28 dias de idade, das aves das 12 linhagens experimentais e do material comercial são apresentados na Figura 2. Verificaram-se grandes variações na taxa de crescimento das linhagens, tanto na comparação entre linhagens de origem diferente, como na comparação entre linhagens de mesma origem. As linhagens (IPEG)3, de origem mais recente, apresentaram em média peso corporal superior ao das linhagens (IPEG)1, de origem mais antiga. $\mathrm{O}$ desempenho médio das linhagens (IPEG)2 mostrou-se similar ao das linhagens (IPEG)3, com relação à taxa de crescimento. Conforme esperado, o material comercial exibiu maior peso que as linhagens experimentais, em função da expressão do vigor de híbrido próprio do mesmo.

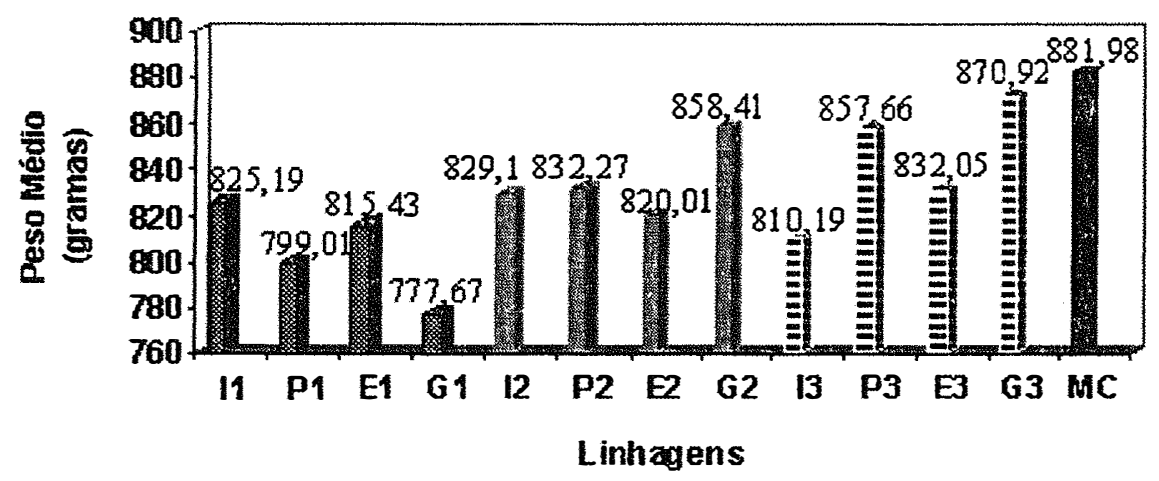

Figura 2. Peso médio (gramas) aos 28 dias de idade das linhagens experimentais e do material comercial (MC) 
A análise de variância dos 5658 pesos individuais obtidos encontra-se na Tabela 5. Constataram-se diferenças significativas $(P<0,01)$ em relação a origem das aves (linhagem). O efeito "Incubação", correspondente as 16 semanas consecutivas nas quais se obtiveram as aves avaliadas, também apresentou diferenças significativas $(\mathrm{P}<0,01)$, associadas a condições ambientais que não puderam ser totalmente uniformizadas durante o período experimental. Como era previsto, para o efeito "Sexo" verificam-se diferenças significativas $(\mathrm{P}<0,01)$ decorrentes do dimorfismo sexual, mostrando-se os machos mais precoces e portanto, atingindo maior peso corporal que as fêmeas. A interação entre os efeitos "Linhagem" e "Incubação" (L X I) foi significativa $(\mathrm{P}<0,01)$, mostrando a existência de respostas diferenciadas entre os materiais avaliados para peso corporal, em função das variações ambientais verificadas.

Tabela 5. Análise de variância do peso corporal aos 28 dias de idade das aves das linhagens experimentais e do material comercial.

\begin{tabular}{lrc}
\hline \multicolumn{1}{c}{ Fontes de Variação } & G.L. & Quadrádos Médios \\
\hline Linhagem (L) & 12 & $273078,03^{* *}$ \\
Incubação (I) & 15 & $356324,51^{* *}$ \\
Sexo (S) & 1 & $11656248,88^{* *}$ \\
L X I & 180 & $34915,45^{* *}$ \\
Resíduo & 5449 & 68578060,81 \\
\hline$* *=$ significativo a 1\% &
\end{tabular}

Em função da significância observada na comparação dos pesos corporais dos materiais avaliados, procedeu-se ao teste das diferenças entre as médias dos mesmos (Tabela 6). Verificaram-se várias diferenças significativas $(\mathrm{P}<0,01)$ no desempenho médio dos materiais. A linhagem experimental G3 apresentou peso corporal semelhante ao do material comercial; a linhagem G1 atingiu $88,17 \%$ do 
desempenho médio do material comercial, sendo que somente a linhagem P1 teve desempenho semelhante a esta.

Tabela 6. Comparação das médias de peso corporal aos 28 dias das linhagens experimentais e do material comercial (MC).

\begin{tabular}{ccc}
\hline Linhagem & Peso Médio \\
\hline MC & 881,98 a \\
G3 & 870,92 ab \\
G2 & 858,41 bc \\
P3 & 857,66 & cd \\
P2 & 832,27 & de \\
E3 & 832,05 & e \\
I2 & 829,10 & e \\
I1 & 825,19 & ef \\
E2 & 820,01 & ef \\
E1 & 815,43 & fg \\
I3 & 810,19 & g \\
P1 & 799,01 & gh \\
G1 & 777,67 & h \\
\hline
\end{tabular}

$a, b, \ldots h=$ médias seguidas da mesma letra, na mesma coluna, não diferem significativamente $(P<0,01)$

Na Figura 3 são representados graficamente os contrastes entre as médias globais envolvendo as linhagens experimentais (IPEG)1, (IPEG)2 e (IPEG)3, e o material comercial (MC). As diferenças entre as médias envolvidas nos contrastes entre o MC e os três diferentes grupos das linhagens experimentais foram significativas $(\mathrm{P}<0,01)$. Os contrastes das médias de (IPEG) 1 com os dois outros grupos das linhagens também apresentaram diferenças significativas $(\mathrm{P}<0,01)$; por sua vez, o contraste entre as médias dos dois grupos (IPEG)2 e (IPEG)3 não apresentou diferenças significativas. 


\begin{tabular}{|c|c|c|c|c|}
\hline & MC & (IPEG)1 & (IPEG)2 & $($ IPEG)3 \\
\hline MC & & - & & \\
(IPEG)1 \\
(IPEG)2 \\
(IPEG)3
\end{tabular}

$(-)=$ diferenças significativas $(\mathrm{P}<0,01)$

Figura 3. Representação gráfica dos contrastes envolvendo as médias do peso corporal entre o material comercial (MC) e os diferentes grupos das linhagens experimentais [(IPEG)1, (IPEG)2 e (IPEG)3]

$\mathrm{Na}$ Tabela 7 são apresentadas comparações entre as médias dos pesos corporais das 16 incubações avaliadas aos 28 dias de idade. Constataram-se diversas diferenças significativas $(\mathrm{P}<0,01)$, em concordância com a significância verificada na análise de variância (Tabela 5) para incubação. Apesar das medidas tomadas visando homogenização das condições às quais os materiais experimentais dessas 16 incubações foram submetidos, tais como: padronização dos equipamentos utilizados na criação, manejo da alimentação, controle sanitário e densidade populacional, devido ao extenso período envolvido nessas avaliações (132 dias), as variações climáticas ocorridas durante o mesmo, podem ter influenciado o desempenho das aves, sendo apontadas como possíveis causas dessas diferenças entre as incubações. As quatro últimas incubações $\left(13^{\mathfrak{a}}\right.$ a $\left.16^{\mathfrak{a}}\right)$, avaliadas no final do período experimental (meses de Setembro e Outubro), apresentaram pesos corporais significativamente $(\mathrm{P}<0,01)$ superiores as incubações avaliadas no início do período experimental (meses de Julho e Agosto). 
Tabela 7. Pesos médios corporais aos 28 dias de idade das 16 incubações.

\begin{tabular}{|c|c|}
\hline Incubação & Peso Médio (g) \\
\hline $14^{\mathrm{a}}$ & $905,05 \mathrm{a}$ \\
\hline $15^{\mathrm{a}}$ & $898,46 a b$ \\
\hline $16^{\mathrm{a}}$ & $872,56 \quad b c$ \\
\hline $13^{\underline{a}}$ & 867,71 \\
\hline $11^{\mathrm{a}}$ & 855,81 \\
\hline $12^{\mathrm{a}}$ & 840,48 \\
\hline $1^{\underline{\underline{a}}}$ & 839,22 \\
\hline $4^{\frac{a}{a}}$ & 835,77 \\
\hline $8^{\underline{3}}$ & 820,49 \\
\hline $9^{\mathrm{a}}$ & 817,36 \\
\hline $10^{\mathrm{a}}$ & 816,31 \\
\hline $6^{\underline{a}}$ & 801,35 \\
\hline $3^{\underline{a}}$ & 798,21 \\
\hline $2^{\underline{a}}$ & 793,66 \\
\hline $5^{\mathrm{a}}$ & 774,77 \\
\hline $7^{\underline{a}}$ & 767,28 \\
\hline
\end{tabular}

$a, b, \ldots j=$ médias seguidas da mesma letra, na mesma coluna, não diferem significativamente $(P<0,01)$

As diferenças verificadas entre os pesos corporais de machos e fêmeas foram significativas (Tabela 5), tendo os mesmos apresentado respectivamente os seguintes valores médios : 884,18 e 778,88 gramas. Na Tabela 8 são indicados os dois maiores e os dois menores valores de pesos médios, obtidos para cada sexo nos materiais avaliados. Verificaram-se diferenças significativas $(\mathrm{P}<0,01)$ entre os sexos em todos os materiais. Dentro de cada sexo também foram registradas diferenças significativas entre os materiais. Para os machos, a diferença entre os valores extremos foi de aproximadamente 100 gramas, equivalente a $12 \%$ do valor médio inferior; já para as fêmeas, essa diferença foi de 110 gramas, correspondente a $15 \%$ do valor inferior. 
Tabela 8. Limites superiores e inferiores dos pesos médios corporais aos 28 dias de idade, para cada sexo, nos materiais avaliados.

\begin{tabular}{|c|c|c|}
\hline \multirow[t]{2}{*}{ Linhagem } & \multicolumn{2}{|c|}{ Peso Médio (g) } \\
\hline & Machos & Fêmeas \\
\hline $\mathrm{MC}$ & $935,54 \mathrm{~A} \mathrm{a}$ & $828,43 \mathrm{~B} \mathrm{a}$ \\
\hline G3 & $921,36 \mathrm{~A} \mathrm{a}$ & $820,49 \mathrm{~B} \mathrm{a}$ \\
\hline P1 & $848,85 \mathrm{~A} \quad \mathrm{~b}$ & 749,18 B b \\
\hline G1 & $836,95 \mathrm{~A} \quad \mathrm{~b}$ & $718,39 \mathrm{~B} \quad \mathrm{~b}$ \\
\hline
\end{tabular}

$\mathrm{A}$ e $\mathrm{B}=$ médias seguidas de letras maiúsculas iguais na mesma linha não diferem estatísticamente $(\mathrm{P}<0,01)$.

$\mathrm{a}$ e $\mathrm{b}=$ médias seguidas de letras minúsculas iguais na mesma coluna não diferem estatísticamente $(\mathbf{P}<0,01)$.

\subsection{1 - Estimativas de repetibilidade}

Na Figura 4 são apresentados os pesos corporais médios (least - squares) aos 28 e 35 dias de idade, obtidos com os 1052 pesos registrados na pesagem individual das 526 aves.

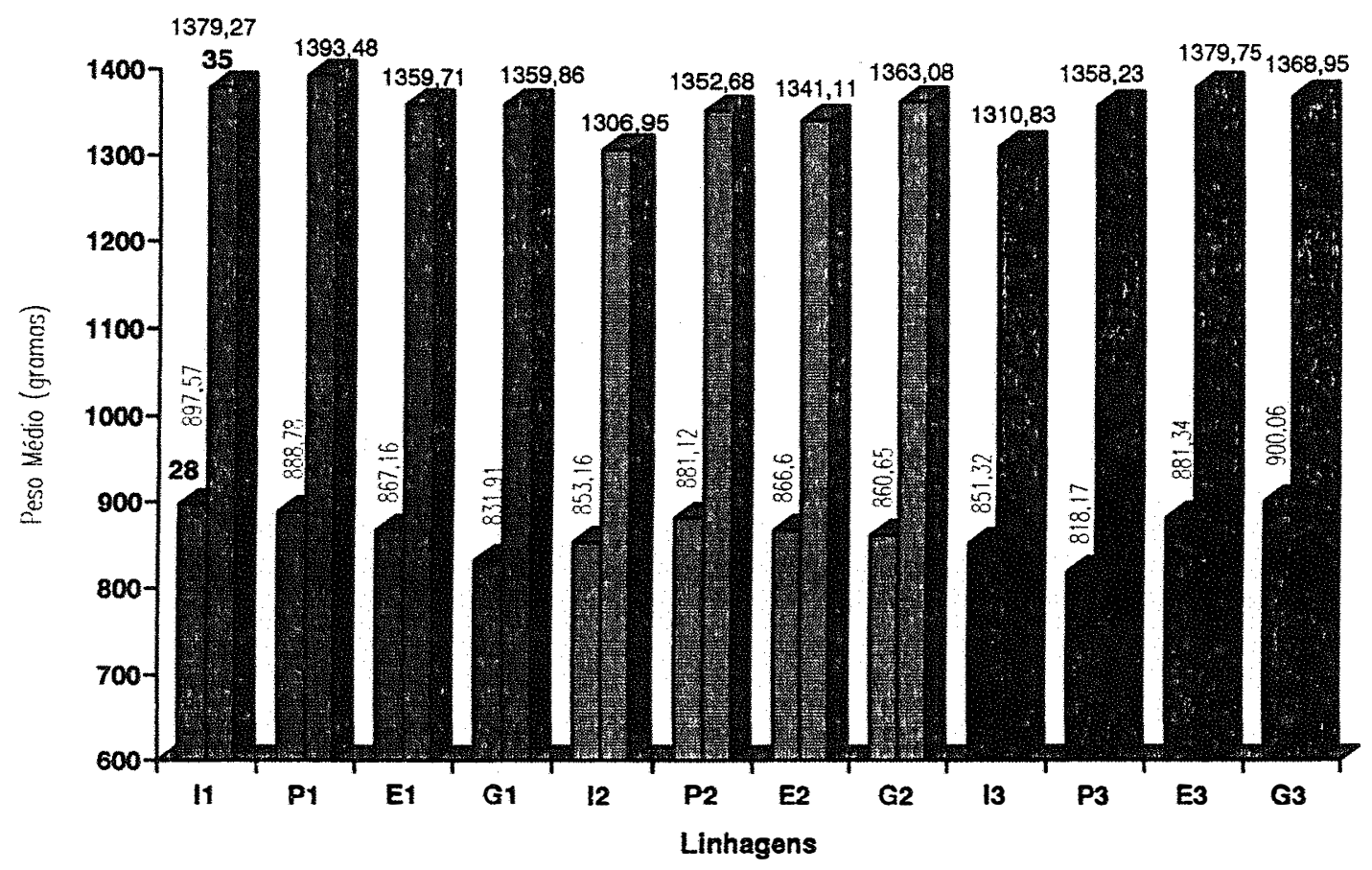

Figura 4. Peso médio (gramas) aos 28 e 35 dias de idade das 12 linhagens experimentais. 
O grande intervalo de variação existente entre os pesos individuais verificados aos 28 e 35 dias de idade tornou obrigatória a transformação dos dados para a realização das análises estatísticas . O coeficiente de variação obtido para os Pesos Relativos (pesos reais transformados) foi de $11,0 \%$. Os resultados das análises estatísticas realizadas são mostrados nas Tabelas 9 e 10. Constataram-se diferenças significativas $(\mathrm{P}<0,05)$ entre os pesos das linhagens e também, diferenças altamente significativas $(\mathrm{P}<0,01)$ entre os pesos das aves avaliadas dentro das linhagens.

Tabela 9. Análise de variância do peso corporal das 12 linhagens experimentais no período de 28 a 35 dias de idade.

\begin{tabular}{lcc}
\hline \multicolumn{1}{c}{ Fontes de Variação } & G.L. & Quadrados Médios $^{1}$ \\
\hline Linhagem (L) & 11 & $378,0584^{*}$ \\
ave $: \mathrm{L}$ & 511 & $203,8153^{* *}$ \\
Resíduo & 529 & 36,0416 \\
\hline
\end{tabular}

$*$ = significativo a $5 \% ; * *$ significativo a $1 \%$.

(1) $\mathrm{QM}_{\text {ave }: L}=\sigma_{\mathrm{c}}^{2}+2,0 \sigma_{\text {ave }: L}^{2}$

As estimativas de repetibilidade obtidas (Tabela 10) são compatíveis com os resultados da literatura; são superiores aos valores de 0,43 a 0,53 registrados por Siegel $(1963 \mathrm{a}, \mathrm{b})$ para estimativas de herdabilidade do peso corporal aos 28 dias de idade de linhagens de "White Plymouth Rocks", mas estão muito próximas das estimativas de herdabilidade obtidas por Ledur et al. (1992) com linhagem experimental de galinhas para corte, iguais a 0,56 e 0,63 respectivamente, aos 28 e 35 dias de idade.

Tabela 10. Estimativas de repetibilidade e erro padrão (E.P.) para peso corporal no período de 28 a 35 dias de idade das linhagens experimentais.

\begin{tabular}{lc}
\hline \multicolumn{1}{c}{ Sexo } & Repetibilidade \pm E.P \\
\hline Machos + Fêmeas & $0,698 \pm 0,022$ \\
Machos & $0,553 \pm 0,042$ \\
Fêmeas & $0,663 \pm 0,035$ \\
\hline
\end{tabular}


A magnitude elevada das estimativas de repetibilidade verificadas para o peso corporal das linhagens experimentais, no período de 28 a 35 dias de idade, evidencia boas perspectivas de progresso genético através de seleção massal com base nesse critério.

\subsection{Análises dos desempenhos reprodutivos}

\subsubsection{Avaliação do desempenho reprodutivo}

O número de observações individuais e os valores das características avaliadas no estudo do desempenho reprodutivo das linhagens encontram-se detalhados no Apêndice. As Figuras 5 e 6 mostram os desempenhos reprodutivos médios das linhagens, obtidos a partir das 1908 observações realizadas ao longo de 16 incubações semanais consecutivas. Os valores médios das características Número de Ovos Incubados (NOI), Número de Ovos Férteis (NOF) e Número de Pintos Nascidos (NPTS) são apresentados na Figura 5.

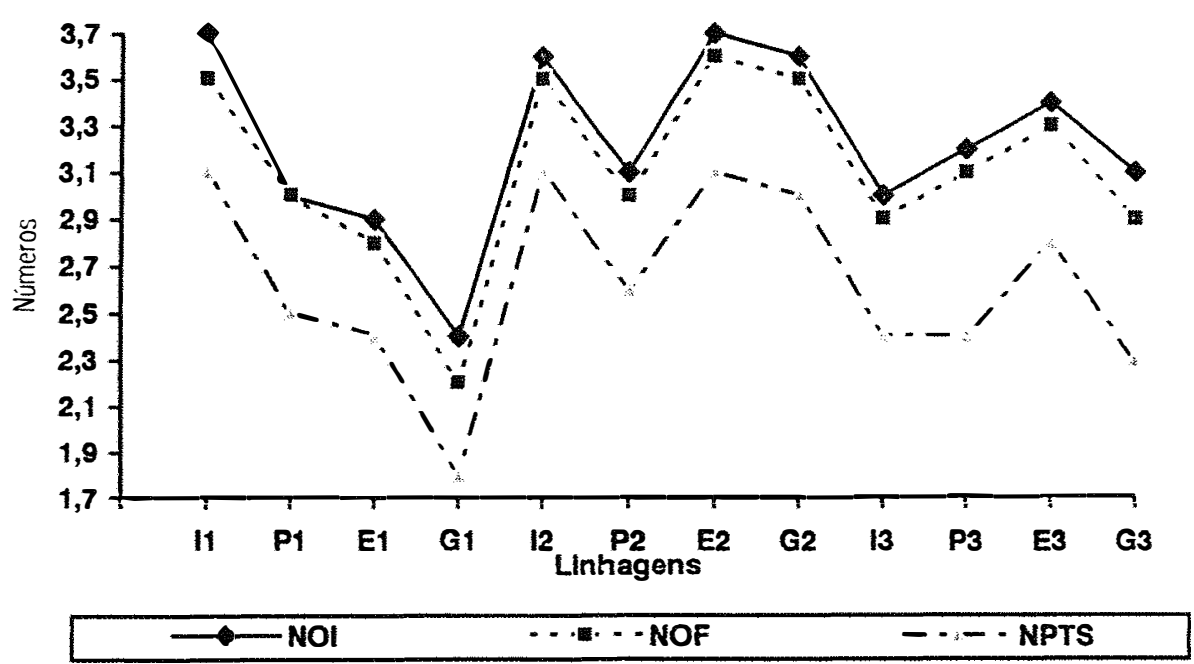

Figura 5. Valores médios verificados para as características Número de Ovos Incubados (NOI), Número de Ovos Férteis (NOF) e Número de Pintos Nascidos (NPTS), na avaliação do desempenho reprodutivo das linhagens. 
As linhagens E2, I1 , G2 e I2 apresentaram os valores médios mais elevados para NOI, NOF e NPTS enquanto que para a linhagem G1 foram verificados os menores valores (Figura 5). A distribuição dos valores médios dessas três características revela grande tendência de associação entre as mesmas. A amplitude de variação das médias dessas características foi de aproximadamente 1,3 indicando a existência de grande diferenças entre as linhagens avaliadas. Na Figura 6 encontramse os valores médios das características Fertilidade \% (FERT), Eclodibilidade \% (ECLOD) e Nascimento \% (NASC).

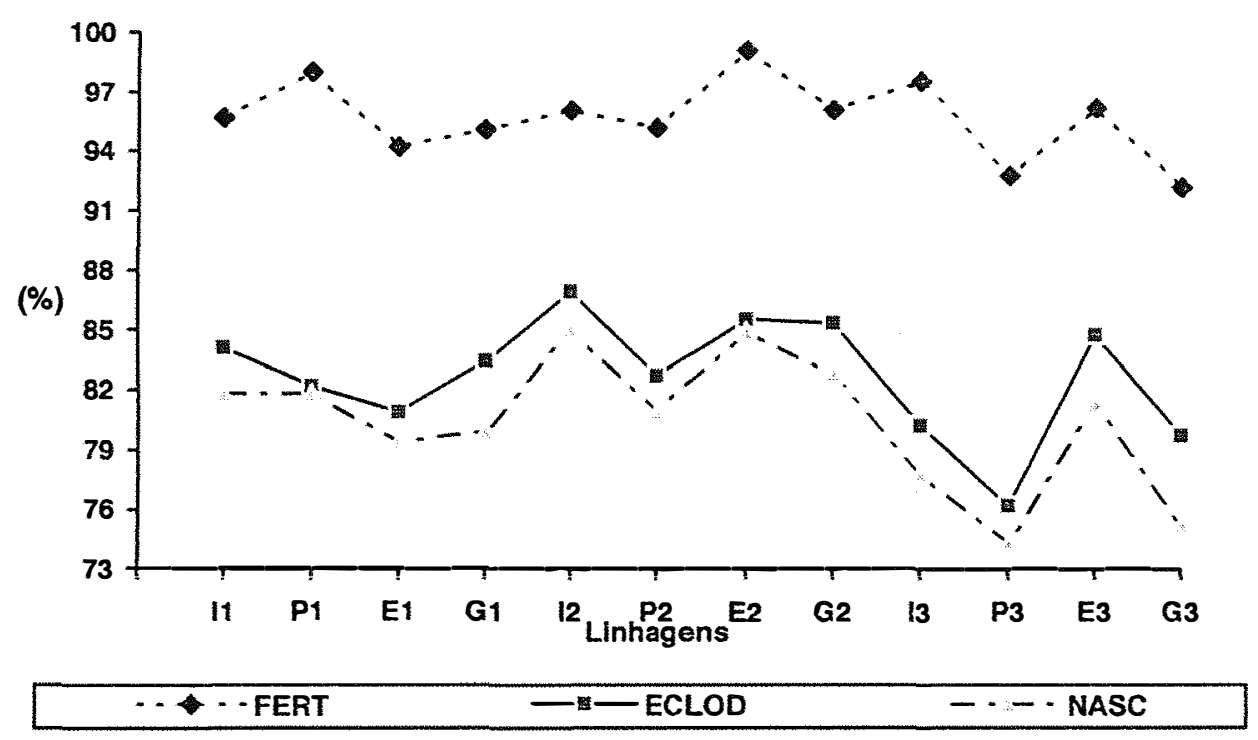

Figura 6. Valores médios verificados para as características Fertilidade \% (FERT), Eclodibilidade \% (ECLOD) e Nascimento \% (NASC), na avaliação do desempenho reprodutivo das linhagens.

As linhagens I2, E2 e P1 apresentaram os valores médios mais elevados para FERT, ECLOD e NASC, enquanto que as linhagens G3 e P3 atingiram os menores valores (Figura 6). A distribuição dos valores médios dessas três características revela tendências de associações entre as mesmas, sugerindo haver maior associação entre ECLOD e NASC do que entre FERT e estas duas. A amplitude de variação das 
médias dessas características esteve entre 7 e 10\%. A análise de variância de NOI, NOF, NPTS, FERT, ECLOD e NASC, é apresentada nas Tabelas 11 e 12.

Tabela 11. Análise de variância das características Número de Ovos Incubados (NOI), Número de Ovos Férteis (NOF) e Número de Pintos Nascidos (NPTS).

\begin{tabular}{lrrrr}
\hline Fontes de Variação & \multirow{2}{*}{ G.L. } & \multicolumn{3}{c}{ Quadrados Médios } \\
\cline { 3 - 5 } & & \multicolumn{1}{c}{ NOI } & NOF & NPTS \\
\hline Linhagens (L) & 11 & $17,94^{* *}$ & $19,24^{* *}$ & $18,70^{* *}$ \\
Galinhas: L & 127 & $9,42^{* *}$ & $9,58^{* *}$ & $9,96^{* *}$ \\
Incubações (I) & 15 & $10,06^{* *}$ & $8,26^{* *}$ & $6,05^{* *}$ \\
L X I & 165 & $1,44 \mathrm{~ns}$ & $1,55 \mathrm{~ns}$ & $1,55 \mathrm{~ns}$ \\
Resíduo & 1589 & 1,54 & 1,61 & 1,62 \\
\hline Média geral + Desvio Padrão & $3,41 \pm 1,23$ & $3,29 \pm 1,26$ & $2,82 \pm 1,26$ \\
\hline ** = significativo a 1\%; ns = não significativo & & &
\end{tabular}

Tabela 12. Análise de variância das características Fertilidade\% (FERT), Eclodibilidade\% (ECLOD) e Nascimento\% (NASC).

\begin{tabular}{|c|c|c|c|c|}
\hline \multirow[t]{2}{*}{ Fontes de Variação } & \multirow[t]{2}{*}{ G.L. } & \multicolumn{3}{|c|}{ Quadrados Médios } \\
\hline & & FERT & ECLOD & NASC \\
\hline Linhagens (L) & 11 & $539,69 * *$ & $1080,91^{*}$ & $1434,50^{* *}$ \\
\hline Galinhas: L & 127 & $335,93 * *$ & $1739,92 * *$ & $1777,27^{* *}$ \\
\hline Incubações (I) & 15 & $446,48^{* *}$ & $2477,86^{* *}$ & $2739,86^{* *}$ \\
\hline L X I & 165 & $189,82 \mathrm{~ns}$ & $470,52 \mathrm{~ns}$ & $504,91 \mathrm{~ns}$ \\
\hline Resíduo & 1589 & 214,10 & 585,71 & 612,63 \\
\hline Média geral & & 95,78 & 83,99 & 81,60 \\
\hline C.V. (\%) & & 15,18 & 28,71 & 30,15 \\
\hline
\end{tabular}

A variação das características reprodutivas estudadas entre as linhagens experimentais (L) foi expressiva, conforme já demonstrado anteriormente (Figuras $5 \mathrm{e}$ 6), e a análise de variância confirmou a significância dessas diferenças para todas as características. As diferenças observadas entre os valores dessas características relativos às diferentes galinhas dentro das linhagens (galinhas:L) também mostraramse significativas $(\mathrm{P}<0,01)$. A variação significativa $(\mathrm{P}<0,01)$ das características estudadas entre as 16 incubações (I) realizadas (Tabelas 11 e 12) evidenciaram a 
influência de fatores ambientais sobre as mesmas, tais como idade das aves, manejo da reprodução das aves e da incubação dos ovos. A interação das linhagens com incubações (L X I) não foi significativa para todas as características, mostrando respostas uniformes das linhagens experimentais às variações ambientais a que foram submetidas, durante o período de avaliação das características reprodutivas. As comparações entre as médias (least-squares) estimadas para as seis características apontam as principais diferenças entre as linhagens experimentais (Tabelas 13 e 14).

Tabela 13. Teste das médias (least-squares) estimadas para as características: Número de Ovos Incubados (NOI), Número de Ovos Férteis (NOF) e Número de Pintos Nascidos (NPTS).

\begin{tabular}{|c|c|c|c|c|c|c|c|c|c|}
\hline \multirow[t]{2}{*}{ Classificação } & \multicolumn{3}{|c|}{$\mathrm{NOI}$} & \multicolumn{3}{|c|}{ NOF } & \multicolumn{3}{|c|}{ NPTS } \\
\hline & \multicolumn{2}{|c|}{ Média } & Linh. & \multicolumn{2}{|c|}{ Média } & Linh. & \multicolumn{2}{|c|}{ Média } & Linh. \\
\hline 1 & $3,718 \mathrm{a}$ & & E2 & $3,683 a$ & & E2 & $3,168 \mathrm{a}$ & & E2 \\
\hline 2 & $3,708 \mathrm{a}$ & & I1 & $3,598 \mathrm{a}$ & & I1 & $3,137 \mathrm{at}$ & & 11 \\
\hline 3 & $3,637 a$ & & $\mathrm{G} 2$ & $3,529 \mathrm{a}$ & & 12 & $3,134 \mathrm{at}$ & & 12 \\
\hline 4 & $3,636 a$ & & $\mathrm{I} 2$ & $3,513 \mathrm{a}$ & & G2 & $3,042 \mathrm{at}$ & & G2 \\
\hline 5 & $3,499 \mathrm{ab}$ & & E3 & 3,355 & bc & E3 & 2,883 & & E3 \\
\hline 6 & $3,250 \mathrm{t}$ & & P3 & 3,109 & $\mathrm{~cd}$ & P3 & 2,644 & $\mathrm{~cd}$ & $\mathrm{P} 2$ \\
\hline 7 & 3,194 & $\mathrm{c}$ & $\mathrm{P} 2$ & 3,092 & $\mathrm{~d}$ & $\mathrm{P} 2$ & 2,522 & $\mathrm{~d}$ & $\mathrm{P} 1$ \\
\hline 8 & 3,182 & c & G3 & 3,024 & $\mathrm{~d}$ & P1 & 2,482 & d & P3 \\
\hline 9 & 3,077 & $c$ & $\mathrm{P} 1$ & 2,994 & d & I3 & 2,465 & $\mathrm{~d}$ & I3 \\
\hline 10 & 3,060 & c & I3 & 2,936 & d & G3 & 2,463 & d & E1 \\
\hline 11 & 2,956 & c & $\mathrm{E} 1$ & 2,835 & $d$ & $\mathrm{E} 1$ & 2,398 & d & G3 \\
\hline 12 & 2,417 & $\mathrm{~d}$ & $\mathrm{G} 1$ & 2,296 & $\mathrm{e}$ & G1 & 1,882 & $\mathrm{e}$ & G1 \\
\hline
\end{tabular}

$a, b, \ldots e=$ médias seguidas da mesma letra, na mesma coluna, não diferem significativamente $(\mathrm{P}<0,01)$.

As linhagens E2, I1, G2 e I2 apresentaram os maiores valores médios para as características NOI, NOF e NPTS, não havendo diferenças significativas entre elas (Tabela 13); a linhagem G1 apresentou os menores valores médios para essas três características, diferindo significativamente $(\mathrm{P}<0,01)$ das demais linhagens experimentais. O conjunto constituído pelas linhagens P3, P2, G3, P1, I3 e E1 apresentou médias semelhantes, sendo que todas apresentaram desempenhos inferiores as médias gerais (Tabela 11) para as características NOI, NOF e NPTS. 
Tabela 14: Teste de médias (least - squares) estimadas para as características Fertilidade \% (FERT), Eclodibilidade \% (ECLOD) e Nascimento \% (NASC).

\begin{tabular}{|c|c|c|c|c|c|c|}
\hline \multirow[t]{2}{*}{ Classificação } & \multicolumn{2}{|c|}{ FERT } & \multicolumn{2}{|c|}{ ECLOD } & \multicolumn{2}{|c|}{ NASC } \\
\hline & Média & Linh. & Média & Linh. & Média & Linh. \\
\hline 1 & $99,186 a b$ & E2 & $86,925 a$ & 12 & $85,079 a$ & 12 \\
\hline 2 & $98,056 \mathrm{ab}$ & P1 & $85,588 \mathrm{ab}$ & E2 & $84,965 a$ & E2 \\
\hline 3 & $97,641 \mathrm{ab}$ & I3 & $85,356 \mathrm{ab}$ & G2 & $82,722 \mathrm{ab}$ & G2 \\
\hline 4 & $96,231 \mathrm{ab}$ & E3 & $84,708 \mathrm{ab}$ & E3 & $81,822 \mathrm{ab}$ & I1 \\
\hline 5 & $96,189 \mathrm{ab}$ & I2 & $84,169 \mathrm{ab}$ & I1 & $81,831 \mathrm{ab}$ & P1 \\
\hline 6 & $96,184 a b$ & G2 & $83,404 a b$ & G1 & $81,370 a b$ & E3 \\
\hline 7 & $95,756 \mathrm{bc}$ & I1 & $82,738 \mathrm{ab}$ & P2 & $80,932 \mathrm{ab}$ & P2 \\
\hline 8 & $95,224 \mathrm{~cd}$ & P2 & $82,292 \mathrm{ab}$ & P1 & $79,927 \mathrm{ab}$ & G1 \\
\hline 9 & 95,164 & G1 & 80,986 bc & E1 & 79,422 bc & E1 \\
\hline 10 & 94,210 & E1 & $80,221 \quad c$ & I3 & $77,888 \quad c$ & $\mathrm{I} 3$ \\
\hline 11 & 92,873 & P3 & 79,750 & G3 & 75,220 & G3 \\
\hline 12 & 92,245 & G3 & 76,280 & P3 & 73,306 & P3 \\
\hline
\end{tabular}

$a, b, \ldots d=$ médias seguidas da mesma letra, na mesma coluna, não diferem significativamente $(\mathrm{P}<0,01)$.

Para a característica FERT as linhagens E2 e P1 apresentaram os maiores valores médios, não diferindo porém das linhagens I3, E3, I2 e G2; a linhagem G3 apresentou a menor média (Tabela 14), não diferindo estatísticamente das linhagens P2, G1, E1 e P3, sendo que estas cinco linhagens proporcionaram médias inferiores a média geral (Tabela 12). As linhagens I2 e E2 atingiram médias mais elevadas para as características ECLOD e NASC, não havendo diferenças significativas entre estas e as linhagens G2, E3, I1, G1, P2 e P1 (Tabela 14); as linhagens P3, G3, I3 apresentaram desempenhos médios significativamente inferiores $(\mathrm{P}<0,01)$, estando as médias das mesmas abaixo das médias gerais (Tabela 12) para essas características.

A comparação entre os diferentes grupos a que pertencem as linhagens para as seis características reprodutivas, obtida através de contrastes é representada graficamente na Figura 7. Os grupos das linhagens (IPEG)1 e (IPEG)2 diferiram significativamente $(\mathrm{P}<0,01)$ para as características NOI, NOF e NPTS. Entre os grupos (IPEG)1 e (IPEG)3 só houve diferença significativa $(\mathrm{P}<0,01)$ para NOI. As 
características NOI, NOF, NPTS, ECLOD e NASC apresentaram diferenças significativas $(\mathrm{P}<0,01)$ entre os grupos (IPEG)2 e (IPEG)3. Com relação à FERT não se observaram diferenças significativas nos contrastes envolvendo os três grupos.

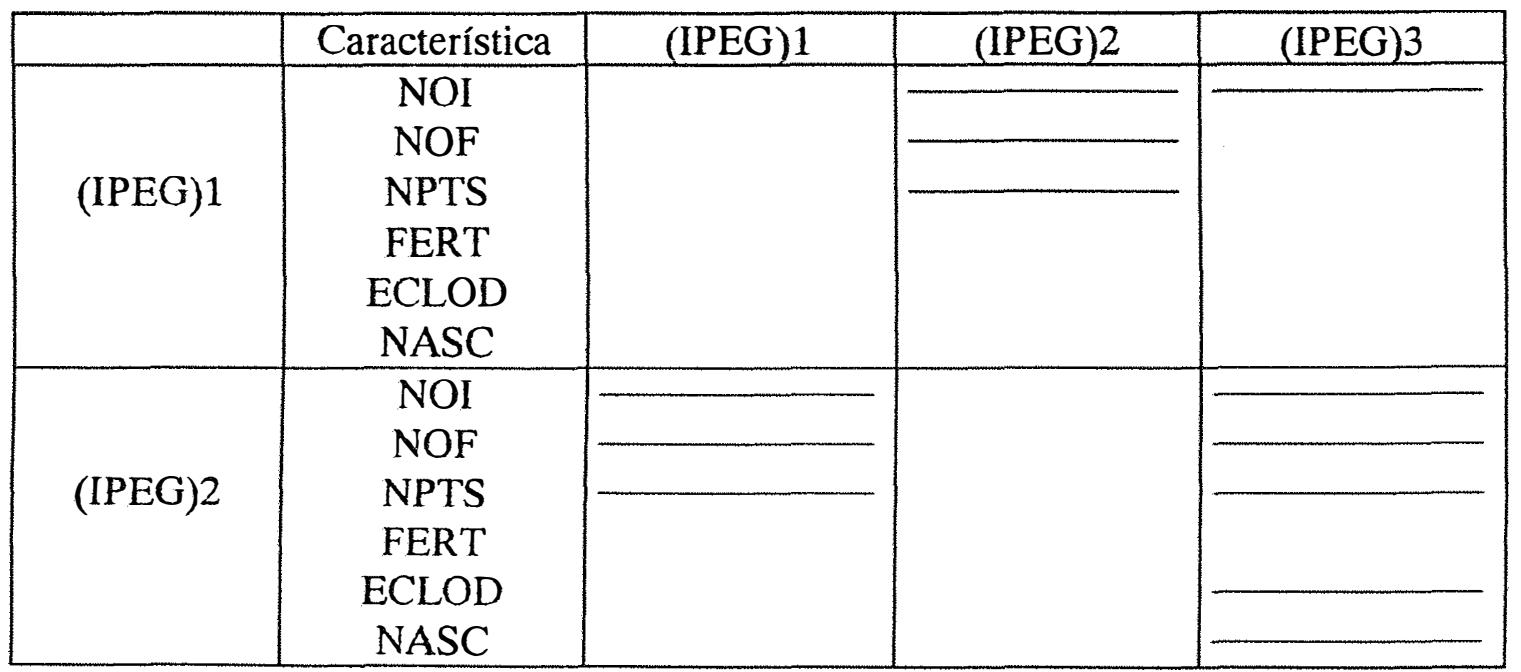

$(-)=$ diferenças significativas $(\mathrm{P}<0,01)$.

Figura 7: Representação gráfica dos contrastes entre os diferentes grupos das linhagens experimentais [(IPEG)1, (IPEG)2 e (IPEG)3], envolvendo as médias das características NOI, NOF, NPTS, FERT, ECLOD e NASC.

As médias gerais obtidas para as características NOI, NOF e NPTS (Tabela 11) foram superiores as encontradas por Custódio (1981) que pesquisando a eficiência reprodutiva de três populações de galinhas para corte (LT, LM e LF) obteve os seguintes valores: 3,1 a 3,2 para NOI, 2,7 a 3,0 para NOF e 2,3 a 2,4 para NPTS. A média geral de FERT $(95,78 \%)$ foi maior que as observadas na literatura: Costa (1980) obteve valores de FERT variando de 58,4 a 91,8 com populações de galinhas para corte; Schmidt et al. (1991 a,b) avaliando características reprodutivas das linhas macho e fêmea de matrizes para corte, encontrou FERT média igual a 90\% nas duas linhas; Ledur et al. (1994) obteve valores médios de FERT de 81,46 e 90,94\% para duas linhagens (KK e PP) da linha fêmea de matrizes de corte e, Savino (1996) encontrou valores médios de FERT de $87,46 \%$ para tratamento testemunha, em experimento sobre tratamento térmico de ovos e vacinação contra micoplasmose de 
reprodutores de corte, e 94,10\% para FERT de ovos não tratados e estocados de 1 a 7 dias antes da incubação, em outro experimento sobre tratamento e estocagem de ovos incubáveis de linhagens de galinhas para corte.

O confronto da média geral obtida para a ECLOD $(83,99 \%)$ com resultados da literatura possibilitou as seguintes comparaçōes: foi superior aos valores de 41,1 a 79,3\% obtidos por Costa (1980), em populações experimentais de galinhas para corte; esteve abaixo dos valores 89 e 92\% encontrados por Schmidt (1991a,b) em linhas macho e fêmea de matrizes para corte e, foi intermediária aos valores de 82,24 e 86,8\% de ECLOD para as linhagens PP e KK da linha fêmea de matrizes de corte, obtidos por Ledur et al.(1994).

Para a característica NASC, a comparação da média geral obtida $(81,60 \%)$ com os resultados da literatura levou ao seguinte quadro: foi superior às médias obtidas por Costa (1980) e Custódio (1981) que obtiveram respectivamente, NASC médios variando de 29,4 a $74,1 \%$ e 66,8 a $74,7 \%$, em populaçōes de galinhas para corte e, foi inferior aos valores 83 e $84,38 \%$ para a média de NASC, obtidos respectivamente por Schmidt et al. (1991 b), com linha fêmea de matrizes para corte, e por Savino (1996) com ovos de galinhas para corte não submetidos a tratamento térmico e estocados de 1 a 7 dias antes da incubação. 


\subsubsection{Determinação de parâmetros genéticos e fenotípicos para características reprodutivas.}

\subsubsection{Estimativas de herdabilidade}

Utilizando-se componentes das análises de variância e covariância, obtidos a partir das 1908 observações registradas nas 16 incubações realizadas, calcularam-se as estimativas de herdabilidade para as características Números de Ovos Incubados (NOI), Número de Ovos Férteis (NOF), Número de Pintos (NPTS), Fertilidade \% (FERT), Eclodibilidade \% (ECLOD) e Nascimento \% (NASC), as quais são apresentadas na Tabela 15.

Tabela 15: Estimativas de herdabilidade $\left(\mathrm{h}^{2}\right)$ para as características reprodutivas NOI, NOF, NPTS, FERT, ECLOD e NASC.

\begin{tabular}{cc}
\hline Característica & $\mathrm{h}^{2} \pm$ Desvio padrão \\
\hline NOI & $0,283 \pm 0,030$ \\
NOF & $0,276 \pm 0,030$ \\
NPTS & $0,288 \pm 0,030$ \\
FERT & $0,046 \pm 0,014$ \\
ECLOD & $0,136 \pm 0,022$ \\
NASC & $0,134 \pm 0,021$ \\
\hline
\end{tabular}

A estimativa de herdabilidade obtida para o caráter NOI foi superior a observada por Custódio (1981), que estudando a variabilidade fenotípica para a eficiência reprodutiva de três populações de galinhas para corte, obteve o valor de 0,061 para essa estimativa, em análise conjunta das três populações. Para as características NOF e NPTS, os valores das estimativas apresentados na Tabela 15 foram semelhantes aos obtidos por Custódio (1981) no referido estudo, tendo o mesmo encontrado os valores de 0,265 e 0,237 respectivamente, para NOF e NPTS.

Com relação a estimativa obtida para o caráter FERT, o valor apresentado foi superior ao relatado por Crittenden et al. (1957), que realizando acasalamentos 
hierárquicos completos, em um plantel de "New Hamphsires", encontrou o valor de 0,005 para essa estimativa. Souza \& Custódio (1977) utilizando acasalamentos em massa, em três populações de galinhas para corte, obteve o valor de 0,09 para a estimativa da herdabilidade da FERT, valor esse superior ao apresentado na Tabela 15. Schmidt et al. (1991c) também observaram valores superiores; pesquisando parâmetros genéticos e fenotípicos para características reprodutivas de aves de duas linhas fêmea, os autores encontraram os valores de 0,23 e 0,50 para a estimativa de herdabilidade de FERT. Savino (1996), avaliando os efeitos da vacinação de reprodutores contra micoplasmose e do tratamento térmico de ovos, sobre o desempenho reprodutivo de 12 linhagens de galinhas para corte, obteve estimativa de repetibilidade igual a 0,203 para a FERT, com resultados de aves não vacinadas e ovos não tratados, sendo esse valor também superior ao da Tabela 15.

O valor observado para a estimativa de herdabilidade do caráter ECLOD foi de maior magnitude que o verificado para a FERT (Tabela 15). Com relação aos valores dessa estimativa relatados na literatura, o valor obtido neste trabalho foi semelhante aos encontrados nos estudos a seguir descritos. Costa (1980), analisando a herança de caracteres reprodutivos em três populações de galinhas para corte, relatou estimativa de herdabilidade para ECLOD igual a 0,136, a partir de componentes de variância entre galos. Ledur et al. (1994), estimando parâmetros genéticos para características reprodutivas em linha de fêmea, obtiveram estimativa de herdabilidade para ECLOD, a partir da correlação intraclasse entre meias-irmãs paternas, igual a 0,13. Custódio (1997), estudando a herança de caracteres reprodutivos em galinhas para corte encontrou estimativas de repetibilidade para ECLOD variando de 0,10 a 0,17 .

A estimativa de herdabilidade da característica NASC apresentou magnitude semelhante a do caráter ECLOD (Tabela 15). Na comparação da mesma com os resultados relatados na literatura constataram-se as seguintes observações: seu valor esteve próximo ao encontrado por Zaborowsky \& Custódio (1978), que obtiveram 
repetibilidade igual a 0,12 para NASC, a partir de dados não transformados, em duas populações de galinhas para corte; foi intermediária aos valores apresentados por Souza (1978), que encontrou valores de repetibilidade para NASC variando de 0,07 a 0,24 , calculados a partir de médias de duas populações de galinhas para corte e, mostrou-se inferior as estimativas de herdabilidade relatadas por Schmidt et al. (1991c), que observaram os valores de 0,21 e 0,37 para a estimativa de herdabilidade de NASC, em duas linhas de fêmea de corte em desenvolvimento no CNPSA.

\subsubsection{Correlações genéticas, fenotípicas e ambientais}

As correlações genéticas, fenotípicas e ambientais verificadas entre as características reprodutivas Número de Ovos Incubados (NOI), Número de Ovos Férteis (NOF), Número de Pintos Nascidos (NPTS), Fertilidade \% (FERT), Eclodibilidade \% (ECLOD) e Nascimento \% (NASC) são apresentadas na Tabela 16.

Tabela 16. Correlações genéticas $\left(\mathrm{r}_{\mathrm{g}}\right)$ com desvios-padrão, e correlações fenotípicas $\left(r_{f}\right)$ e ambientais $\left(r_{a}\right)$, entre as características NOI, NOF, NPTS, FERT, ECLOD e NASC.

\begin{tabular}{cccc}
\hline Características & $\left(\mathrm{r}_{\mathrm{g}} \pm\right.$ desvio-padrão $)$ & $\left(\mathrm{r}_{\mathrm{f}}\right)$ & $\left(\mathrm{r}_{\mathrm{a}}\right)$ \\
\hline NOI x NOF & $0,996 \pm 0,002$ & 0,968 & 0,958 \\
NOI x NPTS & $0,946 \pm 0,013$ & 0,865 & 0,832 \\
NOI x FERT & $0,393 \pm 0,143$ & 0,113 & 0,082 \\
NOI x ECLOD & $0,401 \pm 0,103$ & 0,140 & 0,078 \\
NOI x NASC & $0,393 \pm 0,104$ & 0,121 & 0,056 \\
NOF x NPTS & $0,958 \pm 0,010$ & 0,890 & 0,863 \\
NOF x FERT & $0,462 \pm 0,131$ & 0,316 & 0,318 \\
NOF x ECLOD & $0,427 \pm 0,101$ & 0,168 & 0,108 \\
NOF x NASC & $0,431 \pm 0,100$ & 0,215 & 0,167 \\
NPTS x FERT & $0,530 \pm 0,128$ & 0,268 & 0,252 \\
NPTS x ECLOD & $0,651 \pm 0,071$ & 0,511 & 0,487 \\
NPTS x NASC & $0,655 \pm 0,071$ & 0,534 & 0,516 \\
FERT x ECLOD & $0,593 \pm 0,134$ & 0,296 & 0,275 \\
FERT x NASC & $0,656 \pm 0,114$ & 0,480 & 0,472 \\
ECLOD x NASC & $0,989 \pm 0,006$ & 0,945 & 0,938 \\
\hline
\end{tabular}


As correlações genéticas entre ECLOD e NASC, e entre NOF e NPTS revelaram-se de grande magnitude, indicando que esses caracteres são praticamente idênticos. Portanto, a seleção dirigida para quaisquer desses caracteres deverá responder com elevadas respostas correlacionadas. Por outro lado, as características FERT, ECLOD e NASC mostraram-se pouco associadas com NOI. As correlações genéticas das características de contagem NOF e NPTS com as de porcentagem (FERT, ECLOD e NASC) foram menores que as encontradas na literatura; Custódio (1981) relatou as seguintes correlações genéticas, obtidas a partir de análises conjuntas de três populações de galinhas para corte: NOF $\mathrm{x}$ NPTS $=1,058$, NOF $\mathrm{x}$ FERT $=0,859$, NOF $\times$ ECLOD $=0,850$, NOF $\times$ NASC $=0,991$, NPTS $\times$ FERT $=$ 0,961, NPTS $\times$ ECLOD $=0,809$ e, NPTS $\times$ NASC $=0,948$.

A magnitude observada nas correlações genéticas entre as características FERT, ECLOD e NASC foi semelhante a encontrada na literatura. Costa (1980) obteve os valores de 0,546, 0,592 e 0,994 respectivamente, para as correlações FERT $x$ ECLOD, FERT $x$ NASC e ECLOD $x$ NASC, em análises conjuntas de três populações de galinhas para corte. Savino (1996) observou correlação genética de 0,974 entre ECLOD x NASC na análise conjunta de 12 linhagens de galinhas para corte. Custódio (1997) detectou as seguintes correlações: 0,37 e 0,66 entre FERT x ECLOD, 0,56 e 0,78 entre FERT x NASC e, 0,97 e 0,98 entre ECLOD x NASC, estudando a herança de caracteres reprodutivos de três populações de galinhas para corte, em dois experimentos que envolveram seis incubações consecutivas, com período médio de coleta de ovos de 11,5 dias para cada incubação.

A análise da magnitude das correlações ambientais apresentadas na Tabela 16 torna evidente que a ECLOD e NASC são mais igualmente influenciados pelos mesmos fatores ambientais, e que FERT e ECLOD são mais independentes ambientalmente; estas observações concordam com as de Custódio (1981). As maiores correlações ambientais ocorreram entre NOI x NOF, ECLOD x NASC, NOF $x$ NPTS e, NOI x NPTS, sendo que as demais correlações apresentaram magnitudes 
menores, indicando maior independência a mbiental em suas expressões fenotípicas. A correlação FERT x ECLOD foi semelhante ao valor de 0,246 apresentado por Costa (1980) e, foi de maior magnitude que as relatadas por Custódio (1981), Savino (1996) e Custódio (1997) que encontraram respectivamente, os valores de 0,187, 0,032 e $0,09 / 0,18$, para a correlação ambiental entre essas características.

De maneira geral, pode-se observar que a magnitude atingida nas correlações fenotípicas entre as características estudadas acompanhou paralelamente a magnitude das correlações ambientais (Tabela16). As correlações fenotípicas das características de contagem NOF e NPTS com as de porcentagem (FERT, ECLOD e NASC) foram menores que as encontradas na literatura; Custódio (1981) obteve as seguintes correlações: NOF $x$ NPTS $=0,832$, NOF $\times$ FERT $=0,598$, NOF $\times$ ECLOD $=0,371$, NOF $x$ NASC $=0,448$, NPTS $x$ FERT $=0,496$, NPTS $x$ ECLOD $=0,728$ e NPTS $x$ NASC $=0,761$. A correlação entre FERT $x$ ECLOD apresentou valor semelhante ao valor de 0,225 verificado por Costa (1980) e mostrou-se mais elevada que a encontrada por Savino (1996), que observou o valor de 0,029 para a correlação fenotípica entre essas características. A correlação entre FERT x NASC (Tabela 16) foi semelhante as obtidas por Costa (1980) e Savino (1996) apresentadas na Tabela 1. As caracterísitcas ECLOD e NASC confirmaram ser fortemente associadas, tendo-se verificado alto nível de correlação fenotípica entre as mesmas $(0,945)$; a magnitude dessa correlação é equivalente as observadas por Costa (1980), Custódio (1981) e Savino (1996), relatadas na Tabela 1.

\subsection{Análises da variabilidade genética através do "DNA fingerprinting"}

$\mathrm{Na}$ revelação da autoradiografia obtida da membrana contendo os fragmentos das amostras de DNA das 12 linhagens, hibridizados com a sonda R 18.1, detectaramse perfis polimórficos complexos com mais de 40 bandas capazes de identificar cada uma das 12 linhagens (Figura 8). 


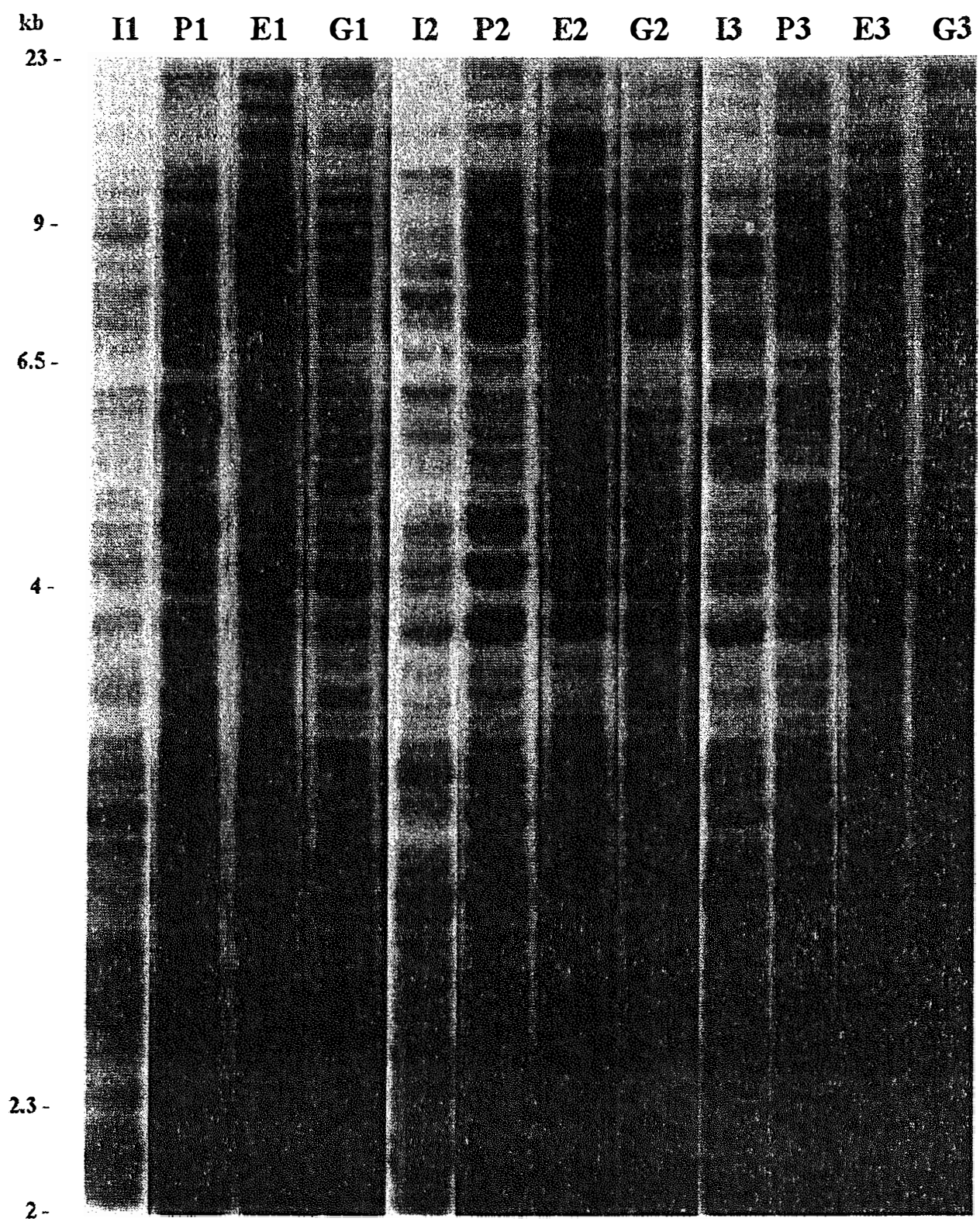

Figura 8. Perfis polimórficos obtidos nas análises de DFP das linhagens experimentais. 
Para a avaliação dos perfis obtidos elegeram-se as 24 bandas mais representativas das amostras de DNA analisadas. Na Figura 9 é apresentado esquematicamente o padrão de distribuição dessas bandas nas 12 linhagens em estudo. A leitura detalhada desse padrão encontra-se no Apêndice.

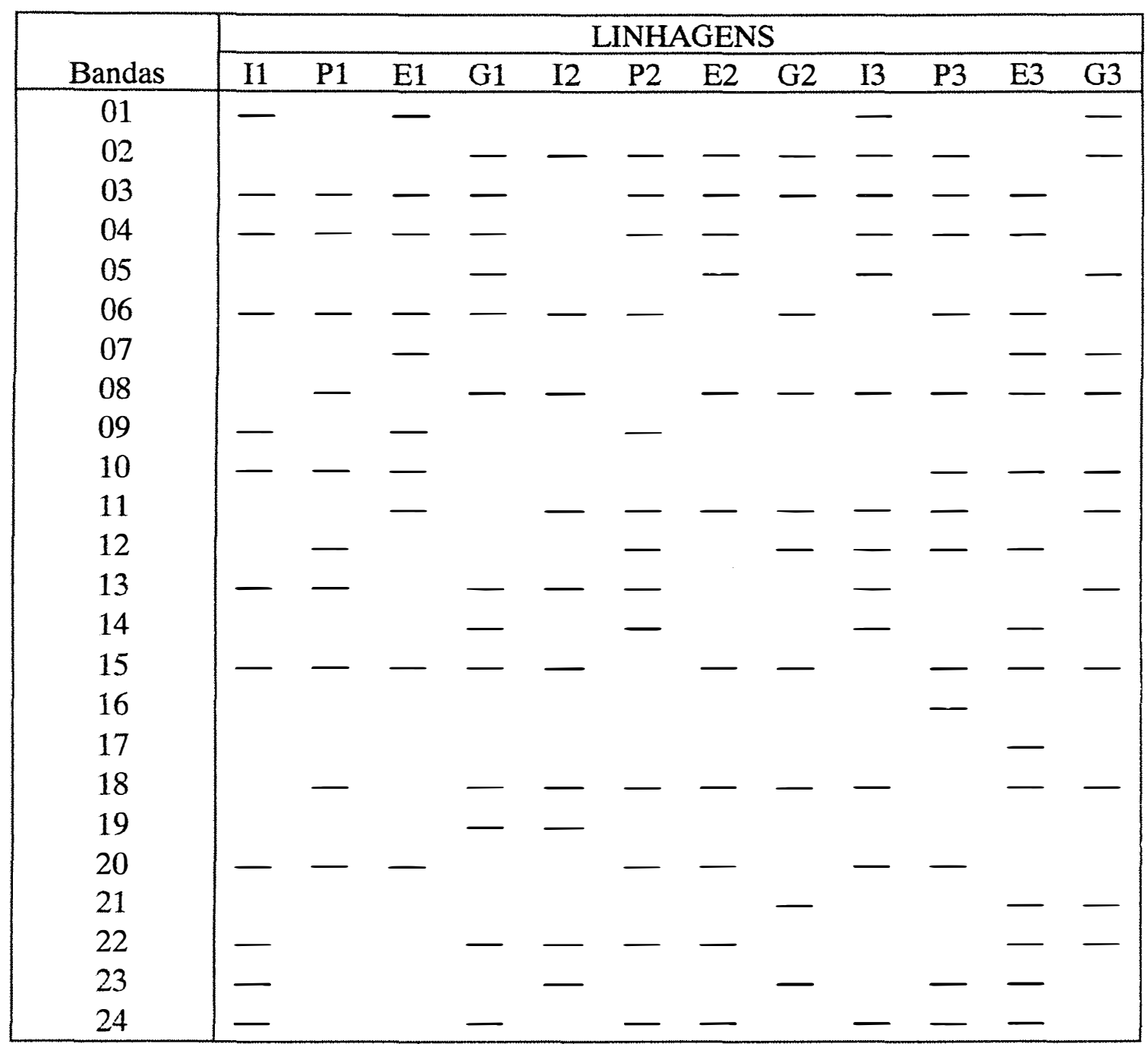

Figura 9. Representação esquemática do padrão de distribuição das 24 bandas mais representativas das amostras de DNA das linhagens. 
Na Tabela 17 são apresentados os índices de similaridade entre as linhagens experimentais calculados através do "bandsharing" (BS). Com esses valores, obtevese o dendograma mostrado na Figura 10.

Tabela 17. Índices de similaridade (bandsharing) calculados com base nas análises de DFP das linhagens.

\begin{tabular}{|c|c|c|c|c|c|c|c|c|c|c|c|c|}
\hline \multirow[b]{2}{*}{ Linhagens } & \multicolumn{12}{|c|}{ LINHAGENS } \\
\hline & I1 & P1 & E1 & G1 & 12 & P2 & $\mathrm{E} 2$ & G2 & 13 & P3 & E3 & G3 \\
\hline I1 & & 0,64 & 0,73 & 0,56 & 0,45 & 0,64 & 0,52 & 0,36 & 0,48 & 0,64 & 0,59 & 0,48 \\
\hline P1 & & & 0,60 & 0,61 & 0,50 & 0,61 & 0,57 & 0,60 & 0,61 & 0,70 & 0,64 & 0,43 \\
\hline E1 & & & & 0,35 & 0,30 & 0,52 & 0,48 & 0,40 & 0,43 & 0,61 & 0,48 & 0,43 \\
\hline G1 & & & & & 0,70 & 0,69 & 0,75 & 0,52 & 0,69 & 0,54 & 0,64 & 0,62 \\
\hline 12 & & & & & & 0,52 & 0,57 & 0,70 & 0,43 & 0,52 & 0,48 & 0,61 \\
\hline P2 & & & & & & & 0,67 & 0,52 & 0,77 & 0,62 & 0,57 & 0,46 \\
\hline E2 & & & & & & & & 0,57 & 0,75 & 0,67 & 0,54 & 0,67 \\
\hline G2 & & & & & & & & & 0,52 & 0,70 & 0,64 & 0,52 \\
\hline 13 & & & & & & & & & & 0,62 & 0,50 & 0,62 \\
\hline P3 & & & & & & & & & & & 0,64 & 0,46 \\
\hline E3 & & & & & & & & & & & & 0,57 \\
\hline
\end{tabular}

A comparação das 12 linhagens através de pares mostrou a existência de expressiva variabilidade nesses materiais genéticos, tendo-se obtido valores de BS variando de 0,30 a 0,77 com média de 0,56. As linhagens 12 e E1 apresentaram o menor índice de similaridade $(B S=0,30)$ sendo que, como já mostrado anteriormente, os pesos médios dessas 2 linhagens diferiram significativamente (Tabela 6) e também, o desempenho reprodutivo das mesmas apresentou diferenças significativas (Tabelas 13 e 14). Entre as linhagens I3 e P2 constatou-se o maior índice de similaridade $(B S=0,77)$, tendo as mesmas apresentado desempenhos semelhantes para as características reprodutivas NOI, NOF e NPTS (Tabela 13) e diferenças significativas para as demais características analisadas. 


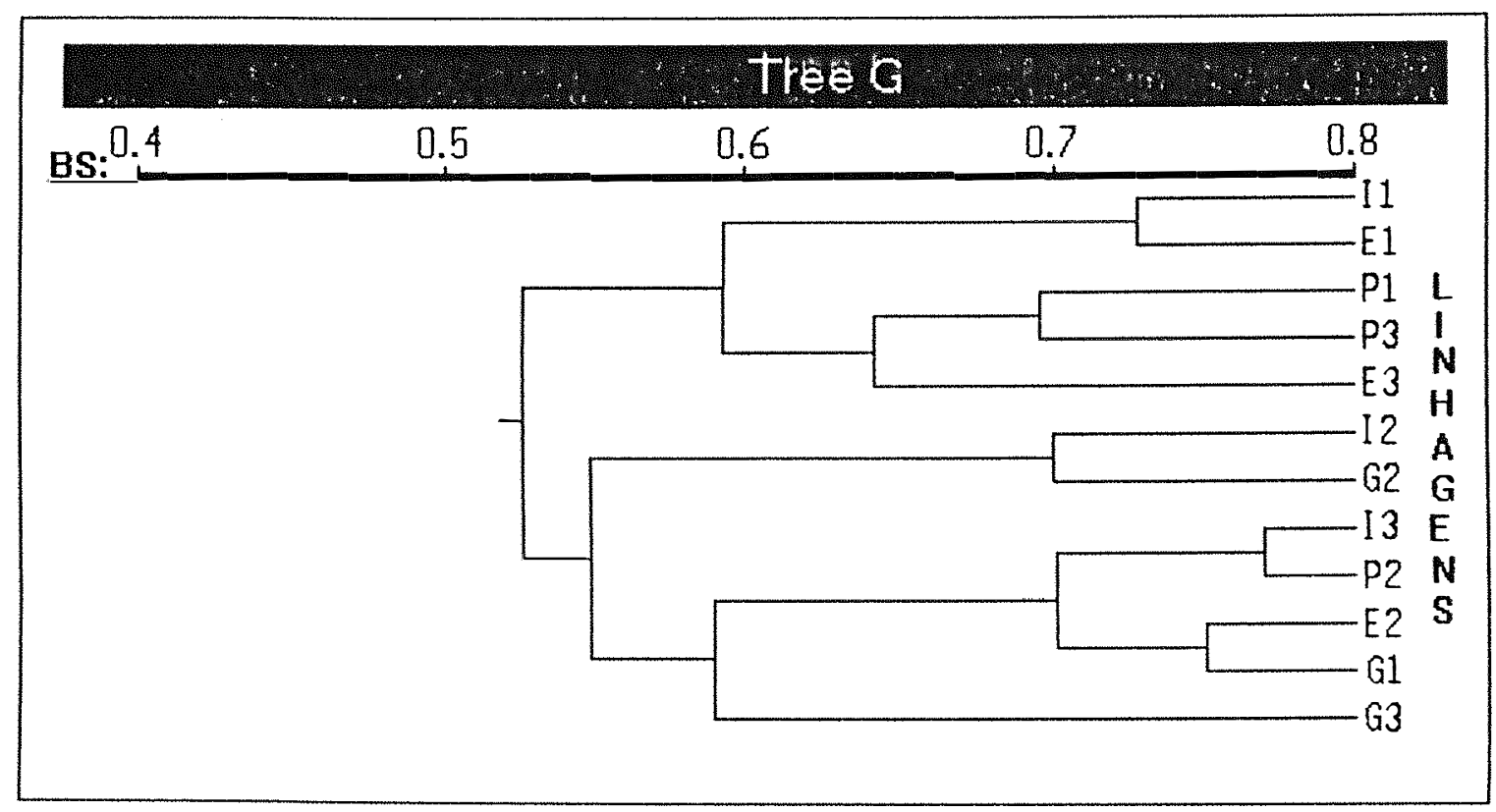

Figura 10. Dendograma com as 12 linhagens agrupadas em função dos índices de similaridade (BS)

O dendograma da Figura 10 representa semelhanças entre linhagens com maiores índices de similaridade (BS). As linhagens I3 e P2 apresentaram BS =0,77 encontrando-se estreitamente unidas no dendograma, enquanto que as linhagens $\mathrm{I} 2 \mathrm{e}$ E1 que demonstraram o menor valor de $\mathrm{BS}(0,30)$ não se mostraram diretamente ligadas no mesmo. 


\section{CONCLUSÕES}

- As linhagens (IPEG)3 apresentaram em média peso corporal aos 28 dias de idade superior ao das linhagens (IPEG)1. O desempenho médio das linhagens (IPEG)2 mostrou-se similar ao das linhagens (IPEG)3, com relação a taxa de crescimento.

- Os pesos corporais das linhagens foram influenciados pelo período de realização da fase de criação; as aves avaliadas em Setembro e Outubro apresentaram maior peso que a avaliadas em Julho e Agosto.

- Como a repetibilidade verificada para o peso corporal das linhagens no período de 28 a 35 dias de idade foi elevada, existem boas perspectivas de melhoramento genético da taxa de crescimento através de seleção massal para essa característica.

- As linhagens apresentaram diferenças no desempenho reprodutivo, com relação às características NOI, NOF, NPTS, FERT, ECLOD e NASC; verificaram-se também variaçōes significativas dessas características nas comparações individuais dentro de cada linhagem. 
- O desempenho reprodutivo das linhagens foi influenciado por fatores ambientais, sendo verificadas respostas uniformes das linhagens às variações ambientais.

- As estimativas de herdabilidade para as características reprodutivas foram de pequena magnitude, sendo que para o caráter FERT encontraram-se os valores mais baixos.

- As elevadas correlações genéticas entre as características NOF X NPTS e ECLOD X NASC indicam que esses caracteres são praticamente idênticos e constituem basicamente diferentes medidas da viabilidade embriônica no período anterior e posterior ao $18^{\mathrm{Q}}$ dia de incubação.

- ECLOD e NASC são características fortemente influenciadas pelos mesmos fatores ambientais esperando-se, portanto, respostas correlacionadas nos desempenhos, com o melhoramento das condições de incubação.

- As análises de "DNA fingerprinting" comprovaram a existência de nível expressivo de variabilidade genética entre as linhagens.

- Os resultados obtidos nas comparações das linhagens pelo "bandsharing" mostraram bom nível de equivalência com as análises de variância e testes de médias efetuadas para as características de crescimento e desempenho reprodutivo. 


\section{REFERÊNCIAS BIBLIOGRÁFICAS}

ABPLANALP, H.; KOSIN, I.L. Genetic variation of fertility and hatchability in the broad breasted bronze turkey. Poultry Science, v. 32, p. 321-331, 1953.

BECKER, W.A.; SPENCER, J.V.; MIROSH, L.W.; VERSTRATE, J.A. Genetic variation of abdominal fat, body weight and carcass weight in a female broiler line. Poultry Science, v. 63, p. 607-611, 1984.

BERNIER, P.E.; TAYLOR, L.W.; GUNNS, C.A. The relative effects of inbreeding and outbreeding on reproduction in the domestic fowl. Hilgardia, v. 20, p. 592-628, 1951.

BOTSTEIN, D.; WHITE, R.L.; SKOLNIC, M.; DAVIS, R.W. Construction of a genetic linkage map in man using restriction fragment length polymorphisms. American Journal of Human Genectis, v. 32, p. 314-331, 1980.

BURKE, T.; BRUFORD, M.W. DNA fingerprinting in birds. Nature, n. 327, p. 149$152,1987$.

COSTA, M.N. Parâmetros genéticos e fenotípicos para caracteres reprodutivos em galinhas para corte. Piracicaba, 1980. 61p. Dissertação (M.S.)-Escola Superior de Agricultura “Luiz de Queiroz", Universidade de São Paulo.

CRAWFORD, R.D. Poultry genetic resources: evolution, diversity and conservation. In: CRAWFORD, R.D. Poultry Breeding and Genetics. Amsterdam: Elsevier Science Publishers, 1990. cap 2, p. 43-60. 
CRITTENDEN, L.B.; BOHREN, B.B.; ANDERSON, V.L. Genetic variance and covariance of the components of hatchability in New Hampshires. Poultry Science, v. 36 , p. 90-103, 1957.

CRITTENDEN, L.B.; BOHREN, B.B. The genetic and environmental effects of hatching time, egg weight and holding time on hatchability. Poultry Science, v. 40, n.6, p. 1736-1750, 1961.

CUSTÓDIO, R.W.S. Análise e interpretação da variabilidade fenotípica para eficiência reprodutiva em galinhas para corte. Piracicaba, 1981. 126p. Tese (Livre-Docência)Escola Superior de Agricultura “Luiz de Queiroz”, Universidade de São Paulo.

CUSTÓDIO, R.W.S. Obtenção de correlações genéticas e ambientais para caracteres reprodutivos em galinhas para corte. Revista Brasileira de Zootecnia, v. 26, n. 2, p. 240-246, 1997.

DALLAS, J.F. Detection of DNA “fingerprints" of cultivated rice by hybridization with a human minisatellite DNA probe. Proceedings of National Academy of Sciences USA, n. 85, p. 6831-6835, 1988.

DUNNINGTON, E.A.; GAL, O.; SIEGEL, P.B.; HABERFELD, A.; CAHANER, A.; LAVI, U.; PLOTSKY, Y.; HILLEL, J. DNA fingerprinting of chickens selected for high and low body-weight for 31 generations. Animal Genetics, v. 21, p. 247-257, 1990.

DUNNINGTON, E,A,; STALLARD, L.C.; HILlEL, J.; SIEGEL, P.B. Genetic diversity among commercial chicken populations estimated from DNA fingerprints. Poultry Science, v. 73, p. 1218-1225, 1994.

DUNNINGTON, E.A.; GAL, O.; SIEGEL, P.B.; HABERFELD, A.; CAHANER, A.; LAVI, U.; PLOTSKY, Y.; HILLEL, J. Deoxyribonucleic acid fingerprinting 
comparisons between selected populations of chickens. Poultry Science, v. 70, p. 463-467, 1991.

EVOLA, S.V.; BURR, F.A.; BURR, B. The suitability of restriction fragment length polymorphisms as genetic markers in maize. Theoretical and Applied Genetics, n. 71, p. 765-771, 1986.

GEORGES, M.; LEQUARRE, A.S; CASTELlI, M.; HANSET, R.; VASSART, G. DNA fingerprinting in domestic animals using four different minisatellite probes. Cytogenetics and Cell Genetics, n. 47, p. 127-131, 1988.

GENTZBITTEL, L.; NICOLAS, P. Improvement of a basic program to construct evolutionary trees from restriction endonuclease data with the use of PASCAL. Journal of Heredity, v. 81, n. 6, p. 491 - 492, 1991.

GOMES, F.P. Curso de Estatística Experimental. $10^{\underline{a}}$ ed. Piracicaba SP : Nobel, 1982. $430 \mathrm{p}$.

GUSE, R.A.; COORS, J.G.; DROLSOM, P.M.; TRACY, W.F. Isozyme marker loci associated with cold tolerance and maturity in maize. Theoretical and Applied Genetics, n. 76, p. 398-404, 1988.

HABERFELD, A.; CAHANER, A.; YOFFE, O.; PLOTSKY, Y.; HILLEL, J. DNA fingerprints of farm animals generated by microssatellite and minissatellite DNA probes. Animal Genetics, n. 22, p. 225-231, 1991.

HABERFELD, A.; DUNNINGTON, E.A.; SIEGEL, P.B. Genetic distances estimated from DNA fingerprints in crosses of White Plymouth Rocks chickens. Animal Genetics, n. 23, p. 167-173, 1992.

HABERFELD, A.; HILLEL, J. Development of DNA fingerprint probes : an approach and its application. Animal Biotechnology, v. 2, p. 61 - 73, 1991. 
HARVEY, W.R. User's guide for LSMLMW and MIXMDL PC - 2 Version (Mixed Model Least - Squares and Maximum Likelihood computer program). s.l. : s. ed., $1990.91 \mathrm{p}$.

HAZEL, L.N. The genetic basis for constructing selection indexes. Genetics, v. 28, p. 476-490, 1943.

HAZEL, L.N.; BAKER, M.L.; REINMILLER, C.F. Genetic and environmental correlations between the growth rates of pigs at different ages. Journal of Animal Science, n. 2, p. 118-128, 1943.

HELENTJARIS, T.; KING, G.; SLOCUM, M.; SIEDENSTRANG, C.; WGEMAN, S. Restriction fragment length polimorphisms as probes for plant diversity and their development as tool for applied plant breeding. Plant Molecular Biology, n. 5, p. 109-118, 1985.

HILLEL, J.; AVNER, R.; BAXTER-JONES, C.; DUNNINGTON, E.A.; CAHANER, A.; SIEGEL, P.B. DNA fingerprints from blood mixes in chickens and in turkeys. Animal Biotechnology, v. 1, n. 2, p. 201-204, 1990.

HILlEL, J.; PLOTZKY, Y.; HABERFELD, A.; LAVI, U.; CAHANER, A.; JEFFREYS, A.J. DNA fingerprints of poultry. Animal Genetics, n. 20, p. 25-35, 1989.

JEFFREYS, A.J.; Highly variable minisatellites and DNA fingerprints. Biochemical Society Transactions, n. 15, p. 309-317, 1987.

JEFFREYS, A.J.; MORTON, D.B. DNA fingerprints of dogs and cats. Animal Genetics, n. 18, p. 1-15, 1987.

JEFFREYS, A.J.; WILSON, V.; THEIN, S.L. Hypervariable "minisatellite" regions in human DNA. Nature, n. 314, p. 67-73, 1985a. 
JEFFREYS, A.J.; WILSON, V.; THEIN, S.L. Individual specific "fingerprints" of human DNA. Nature, n. 316, p. 76-79, 1985 b.

KINNEY JÚNIOR, T.B.; SHOFFNER, R.N. Heritability estimates and genetic correlations among several traits in a meat-type poultry population. Poutry Science, v. 44, n. 4, p. 1020-1032, 1965.

KUHNLEIN, V.; DAWE, Y.; ZADWORNY, D.; GAVORA, J.S. DNA fingerprinting: a tool for determining genetic distances between strains of poultry. Theoretical and Applied Genetics,v. 77, p. 669-672, 1989.

LASLEY, F.J. Genetics of Livestock Improvement. $3^{\underline{a}}$ ed. New Jersey: Prentice - Hall, $1978.350 \mathrm{p}$.

LEDUR, M.C.; SCHMIDT, G.S.; ÁVILA, V.S.; FIGUEIREDO, E.A.P.; MUNARI, D.P. Parâmetros genéticos e fenotípicos para peso corporal em diferentes linhagens de frangos de corte. Revista da Sociedade Brasileira de Zootecnia, v. 21, n. 4, p. 667 $673,1992$.

LEDUR, M.C.; SCHMIDT, G.S.; FIGUEIREDO, E.A.P.; ÁVILA, V.S.; FIORENTIN, L. Parâmetros genéticos e fenotípicos em linhagens de aves selecionadas para corte. Pesquisa Agropecuária Brasileira, v. 29, n. 3, p. 503-508, 1994.

MOYER, S.E.; COLLINS, W.M.; SKOGLUND, W.C. Heritability of body weight at three ages in cross-bred broiler chickens resulting from two systems of breeding. Poultry Science, v. 41, n. 5, p. 1374-1382, 1962.

MUNARI, D.P.; SCHMIDT, G.S.; GIANNONI, M.L. Variabilidade genética e fenotípica do desempenho de uma linhagem de aves Leghorn. 1. Herdabilidades. ARS Veterinária, v. 8, n. 1, p. 49-57, 1992. 
NORDSKOG, A.W.; SMITH, L.T.; PHILLIPS, R.E. Heterosis in poultry. 2. Crossbreds versus top-crossbreds. Poultry Science, v. 38, p. 1372-1380, 1959.

PYM, R.A.E.; NICHOLLS, P.J. Selection for food conversion in broiler: direct and correlated responses to selection for body - weight gain food consumption and food conversion ratio. British Poultry Science, v. 20, n. 1, p. 73-86, 1979.

ROHLF, F.J. Numerical taxonomy and multivariate analysis system - NTSYS - pc. New York : Exeter Software, 1992. 1 v.

SAMBROOK, J.; FRITSCH, E.F.; MANIATIS, T. Molecular cloning : a laboratory manual. $2^{\underline{a}}$ ed. New York : Cold Spring Harbor Laboratory, 1989. 426 p.

SAS user's guide: estatistics. Raleigh: SAS Institute. 1985. 956 p.

SAVINO, V.J.M. Efeitos do tratamento para a erradicação de micoplasma e variabilidade em galinhas para corte. Piracicaba, 1996. 86p. Tese (Doutorado)- Escola Superior de Agricultura “Luiz de Queiroz”, Universidade de São Paulo.

SCHMIDT, G.S.; PACKER, I.U.; DUARTE, F.A.M.; COSTA, C.N. Formação de populações-bases de aves para corte. III. Avaliação das características reprodutivas, linha macho. Pesquisa Agropecuária Brasileira, v. 26, n. 6, p. 785-790, 1991a.

SCHMIDT, G.S.; PACKER, I.U.; DUARTE, F.A.M.; COSTA, C.N. Formação de populações-bases de aves para corte. IV. Avaliação das características produtivas e reprodutivas da linha fêmea. Pesquisa Agropecuária Brasileira, v. 26, n. 6, p. 791 796, $1991 b$.

SCHMIDT, G.S.; ÁVILA, V.S.; LEDUR, M.C.; FIGUEIREDO, E.A.P.; FIORENTIN, L. Parâmetros genéticos e fenotípicos para características de produção e incubação de ovos nas linhas fêmeas de corte KK e PP em desenvolvimento no CNPSA. In 
REUNIÃO ANUAL DA SOCIEDADE BRASILEIRA DE ZOOTECNIA, 28., João Pessoa, 1991. Anais. João Pessoa: s. ed, 1991c. p. 522.

SCHMIDT, G.S.; COSTA, C.N.; LEDUR, M.C.; ÁVILA, V.S. Herdabilidade do peso aos 42 dias de linhagens de aves para corte. Revista da Sociedade Brasileira de Zootecnia, v. 21, n. 5, p. 772-778, 1992.

SIEGEL, P.B. Selection for body weight at eight weeks of age. 1. Short term response and heritabilities. Poultry Science, v. 41, p. 954-962, 1962.

SIEGEL, P.B. Selection for breast angle at eight weeks of age. 2. Correlated responses of feathering, body weights and reproductive characteristics. Poultry Science, v. 42, n. 2, p. 437-449, $1963 \mathrm{a}$.

SIEGEL, P.B. Selection for body weight at eight weeks of age. 2. Correlated responses of feathering, body weights and reproductive characteristics. Poultry Science, v. 42, n. 4, p. 896-905, 1963b.

SIEGEL, P.B.; HABERFELD, A.; MUKHERJEE, T.K.; STALARD, L.C.; MARKS, H.L.; ANTHONY, N.B.; DUNNINGTON, E.A. Jungle fowl-domestic fowl relationships: a use of DNA fingerprinting. World's Poultry Science Journal, v. 48, n. 2, p. 147-155, 1992.

SOLLER, M.; BECKEMANN, J.S. Restriction fragment length polymorphism in poultry breeding. Poultry Science, v. 65, p. 1474-1488, 1986.

SOUTHERN, E.M. Detection of specific sequences among DNA fragments separated by gel electrophoresis. Journal of Molecular Biology, n. 98, p. 503-517, 1975.

SOUZA, P.G. Repetibilidade e correlações entre caracteres reprodutivos em galinhas para corte. Piracicaba, 1978. 57 p. Dissertação (M.S) - Escola Superior de Agricultura “Luiz de Queiróz”, Universidade de São Paulo. 
SOUZA, P.G.; CUSTÓDIO, R.W.S. Repetibilidade e correlações genéticas referentes à características reprodutivas em galinhas para corte. Relatório Científico do Instituto de Genética, n. 11, p. 138-144, 1977.

TANKSLEY, S.D.; MEDINA-FILHO, H.; RICK, C.M. The effect of isozyme selection on metric characteres in an interspecific backcross of tomato - basis of an early screening procedure. Theoretical and Applied Genetics, n. 60, p. 291-296, 1981.

VASSART, G.; GEORGES, M.; MONSIEUR, E.A. A sequence in M13 phage detects hypervariable minisatellites in human and animal DNA. Science, n. 235, p. 683, 1987.

WARREN, D.C. Hybrid vigor in poultry. Poultry Science, v. 7, n. 1, p. 1-8, 1927.

WETTON, J.H.; CARTER, R.E.; PARKIN, D.T.; WALTERS, D. Demographic study of a wild house sparrow population by DNA fingerprinting. Nature, n 327, p. 147 149, 1987.

ZABOROWSKY, S.; CUSTÓDIO, R.W.S. Ganhos genéticos esperados pela seleção direta e indireta para caracteres reprodutivos em galinhas para corte. Relatório Científico do Instituto de Genética, n. 12, p. 303-313, 1978.

ZABOROWSKY, S; CUSTÓDIO, R.W.S.; PACKER, I.U. Herdabilidade da taxa de crescimento nas populações LT, LM e LF. Relatório Científico do Instituto de Genética, n. 11, p. 166-171, 1977.

ZABOROWSKY, S.; CUSTÓDIO, RW.S.; PACKER, I.U. Ganhos genéticos esperados em três populações de galinhas para corte submetidas à seleção massal para maior taxa de crescimento. Relatório Científico do Instituto de Genética, n. 12, p. 314323, 1978. 
APÊNDICE 1. Números de aves avaliadas individualmente de cada material experimental a 16 incubações, empregados nas análises da taxa de crescimento.

\begin{tabular}{|c|c|c|c|c|c|c|c|c|c|c|c|c|c|c|}
\hline \multirow{2}{*}{$\begin{array}{l}\text { Nasci- } \\
\text { mentos }\end{array}$} & \multicolumn{13}{|c|}{ Linhagens } & \multirow[t]{2}{*}{ Totais } \\
\hline & I1 & 12 & 13 & P1 & P2 & P3 & E1 & E2 & E3 & G1 & $\mathrm{G} 2$ & G3 & $\mathrm{MC}$ & \\
\hline 1 & 22 & 32 & 13 & 10 & 31 & 14 & 32 & 15 & 19 & 7 & 12 & 19 & 38 & 264 \\
\hline 2 & 29 & 34 & 20 & 21 & 42 & 16 & 29 & 14 & 35 & 9 & 29 & 26 & 13 & 316 \\
\hline 3 & 25 & 32 & 17 & 16 & 32 & 5 & 30 & 24 & 22 & 8 & 23 & 32 & 148 & 414 \\
\hline 4 & 33 & 39 & 26 & 37 & 11 & 24 & 38 & 31 & 41 & 17 & 37 & 27 & 66 & 427 \\
\hline 5 & 29 & 31 & 17 & 18 & 35 & 20 & 48 & 32 & 39 & 16 & 39 & 30 & 68 & 422 \\
\hline 6 & 34 & 39 & 16 & 21 & 26 & 17 & 36 & 18 & 28 & 11 & 50 & 25 & 83 & 404 \\
\hline 7 & 26 & 36 & 14 & 36 & 23 & 11 & 27 & 14 & 37 & 2 & 29 & 34 & 74 & 372 \\
\hline 8 & 33 & 34 & 21 & 20 & 34 & 13 & 35 & 32 & 30 & 14 & 44 & 28 & 84 & 422 \\
\hline 9 & 21 & 26 & 11 & 26 & 11 & 14 & 19 & 19 & 23 & 10 & 27 & 19 & 57 & 283 \\
\hline 10 & 33 & 22 & 15 & 20 & 23 & 15 & 37 & 37 & 24 & 5 & 39 & 27 & 84 & 381 \\
\hline 11 & 37 & 41 & 20 & 29 & 25 & 13 & 32 & 25 & 33 & 19 & 42 & 22 & 69 & 407 \\
\hline 12 & 24 & 24 & 16 & 17 & 23 & 12 & 38 & 27 & 24 & 17 & 42 & 26 & 19 & 309 \\
\hline 13 & 26 & 24 & 23 & 24 & 20 & 12 & 31 & 34 & 31 & 8 & 45 & 14 & 66 & 358 \\
\hline 14 & 22 & 25 & 9 & 19 & 25 & 15 & 36 & 25 & 23 & 9 & 26 & 15 & 79 & 328 \\
\hline 15 & 19 & 24 & 12 & 1 & 10 & 12 & 28 & 7 & 27 & 1 & 26 & 15 & 62 & 244 \\
\hline 16 & 34 & 22 & 6 & 13 & 23 & 9 & 29 & 23 & 25 & 14 & 11 & 15 & 83 & 307 \\
\hline Totais & 456 & 485 & 256 & 328 & 394 & 221 & 525 & 377 & 461 & 167 & 521 & 374 & 1093 & 5658 \\
\hline
\end{tabular}


APÊNDICE 2. Números de aves das 12 linhagens experimentais envolvidas na obtenção de estimativas de repetibilidade para peso corporal.

\begin{tabular}{|c|c|c|c|c|}
\hline \multirow{2}{*}{ Linhagem } & \multicolumn{3}{|c|}{ Incubação } & Total \\
\cline { 2 - 4 } & $1^{\mathbf{0}}$ & $3^{\underline{0}}$ & $5^{\underline{0}}$ & \\
\hline I1 & 20 & 11 & 24 & 55 \\
I2 & 22 & 16 & 14 & 52 \\
I3 & 13 & 13 & 11 & 37 \\
P1 & 10 & 7 & 10 & 27 \\
P2 & 19 & 16 & 19 & 54 \\
P3 & 9 & 4 & 13 & 26 \\
E1 & 23 & 14 & 24 & 61 \\
E2 & 11 & 13 & 16 & 40 \\
E3 & 17 & 10 & 25 & 52 \\
G1 & 4 & 4 & 8 & 16 \\
G2 & 11 & 13 & 27 & 51 \\
G3 & 19 & 20 & 16 & 55 \\
\hline Totais & 178 & 141 & 207 & 526 \\
\hline
\end{tabular}


옹

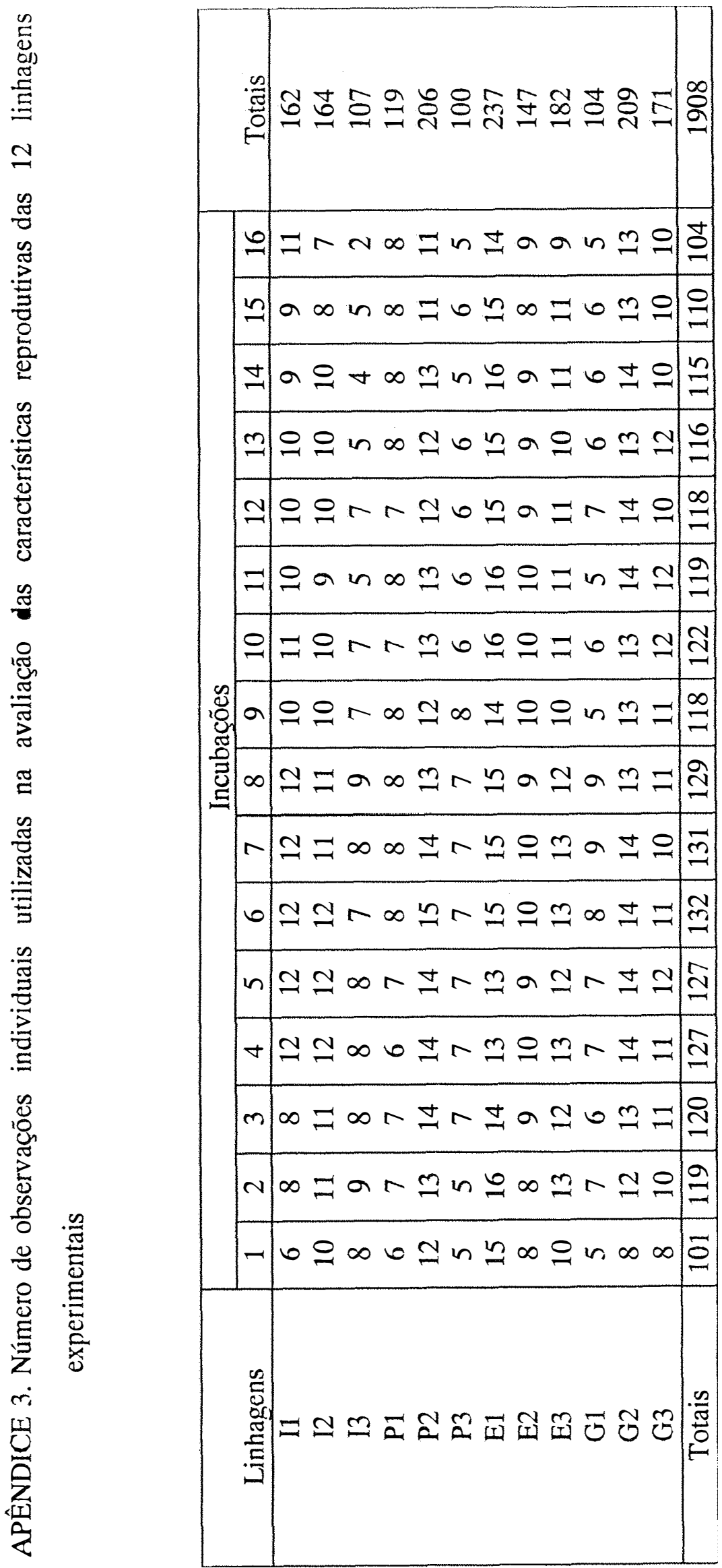




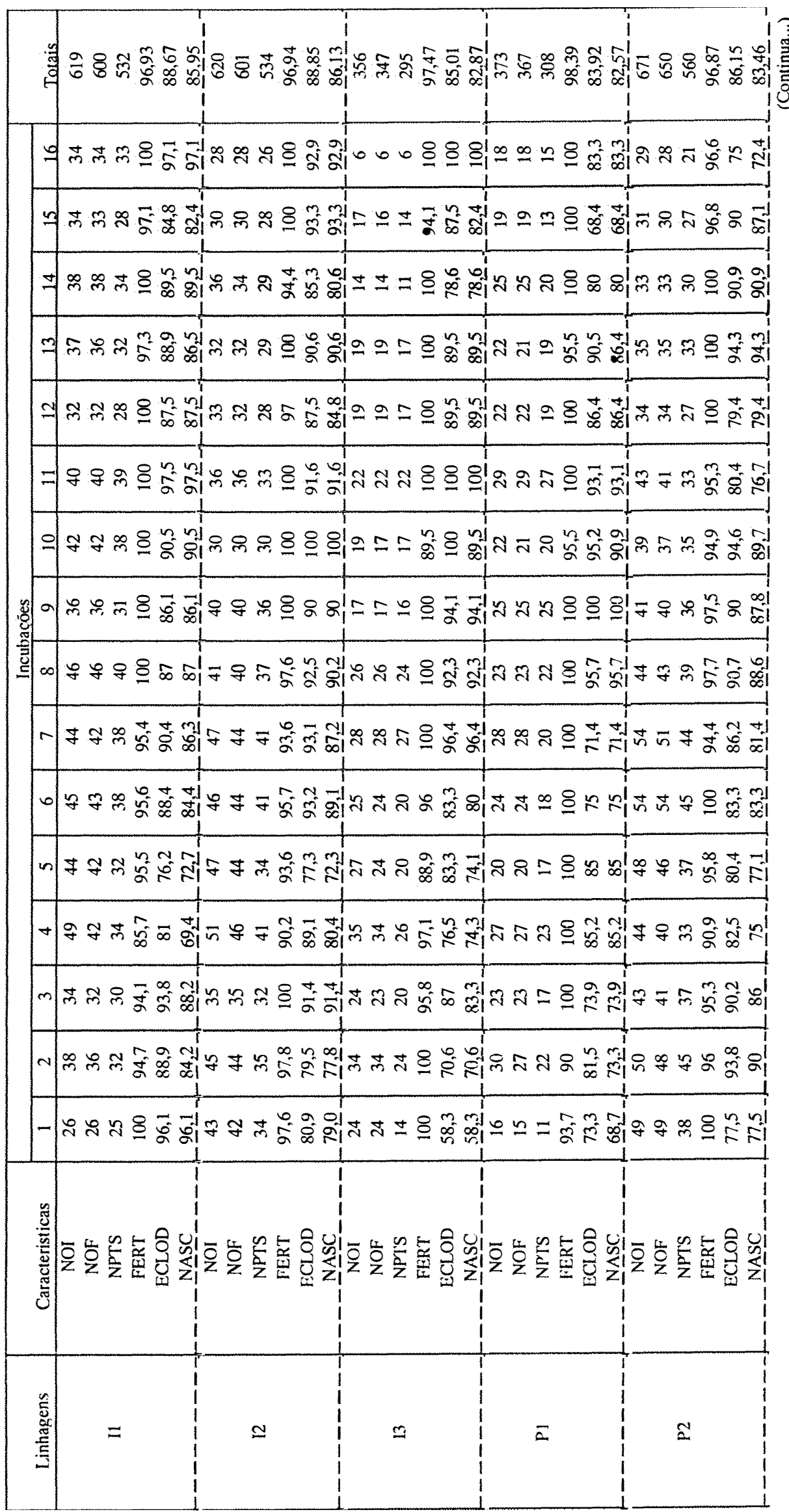




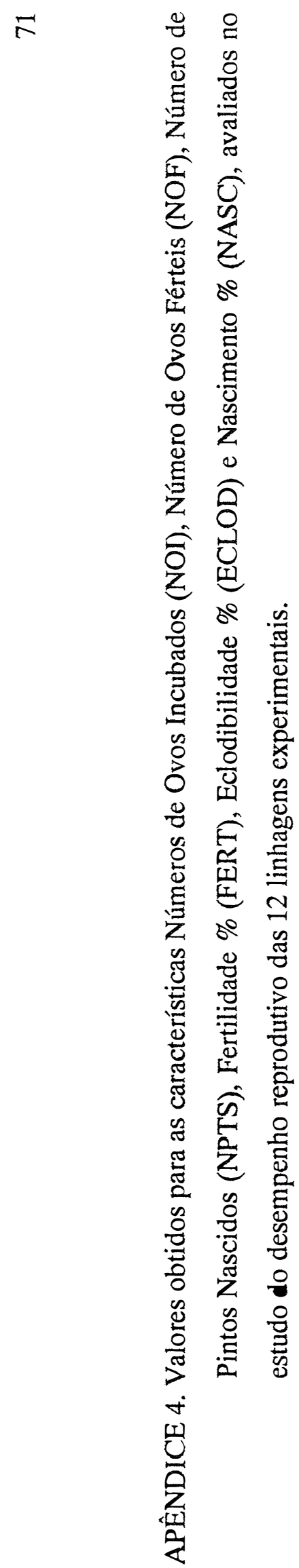

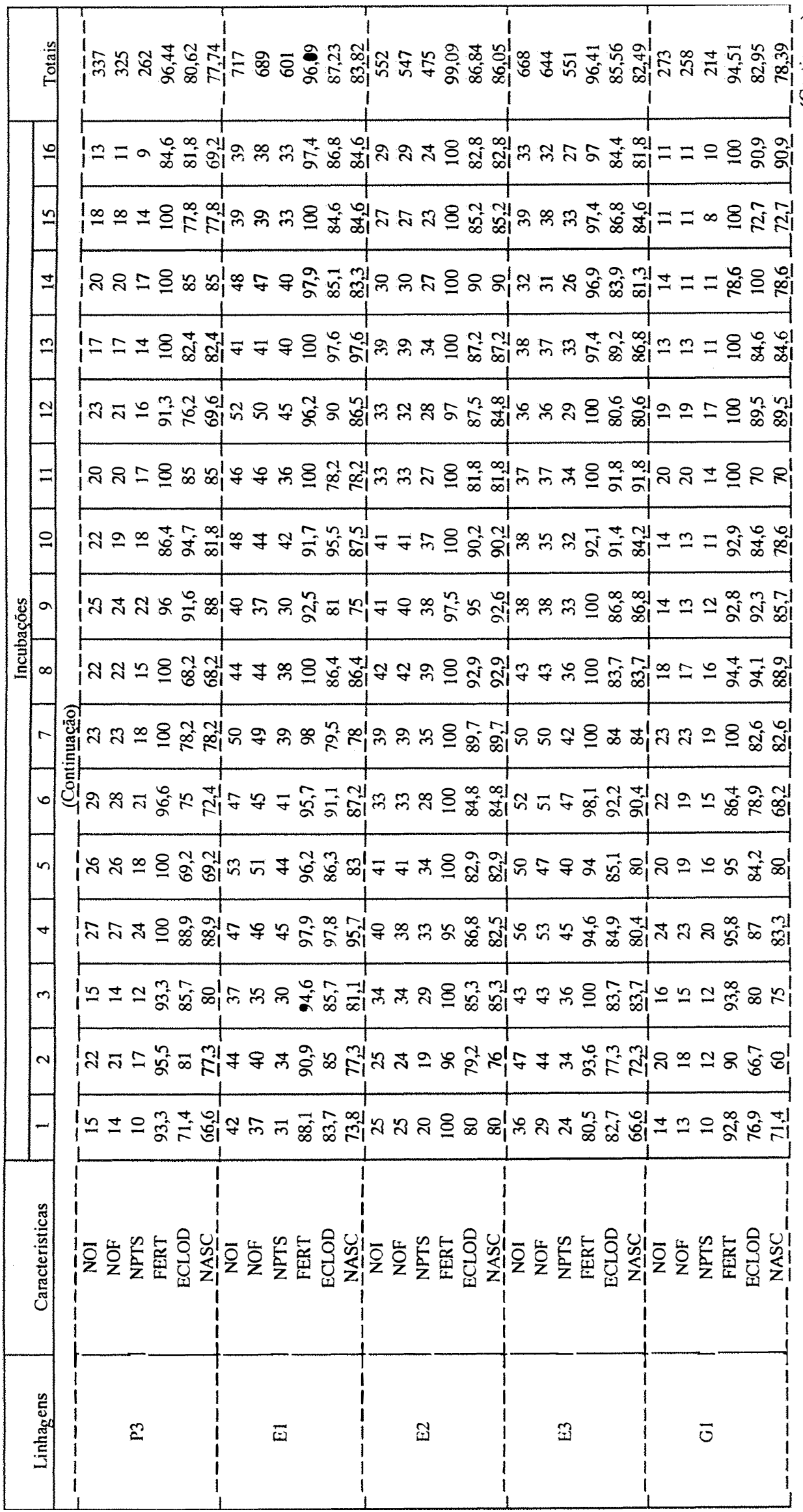




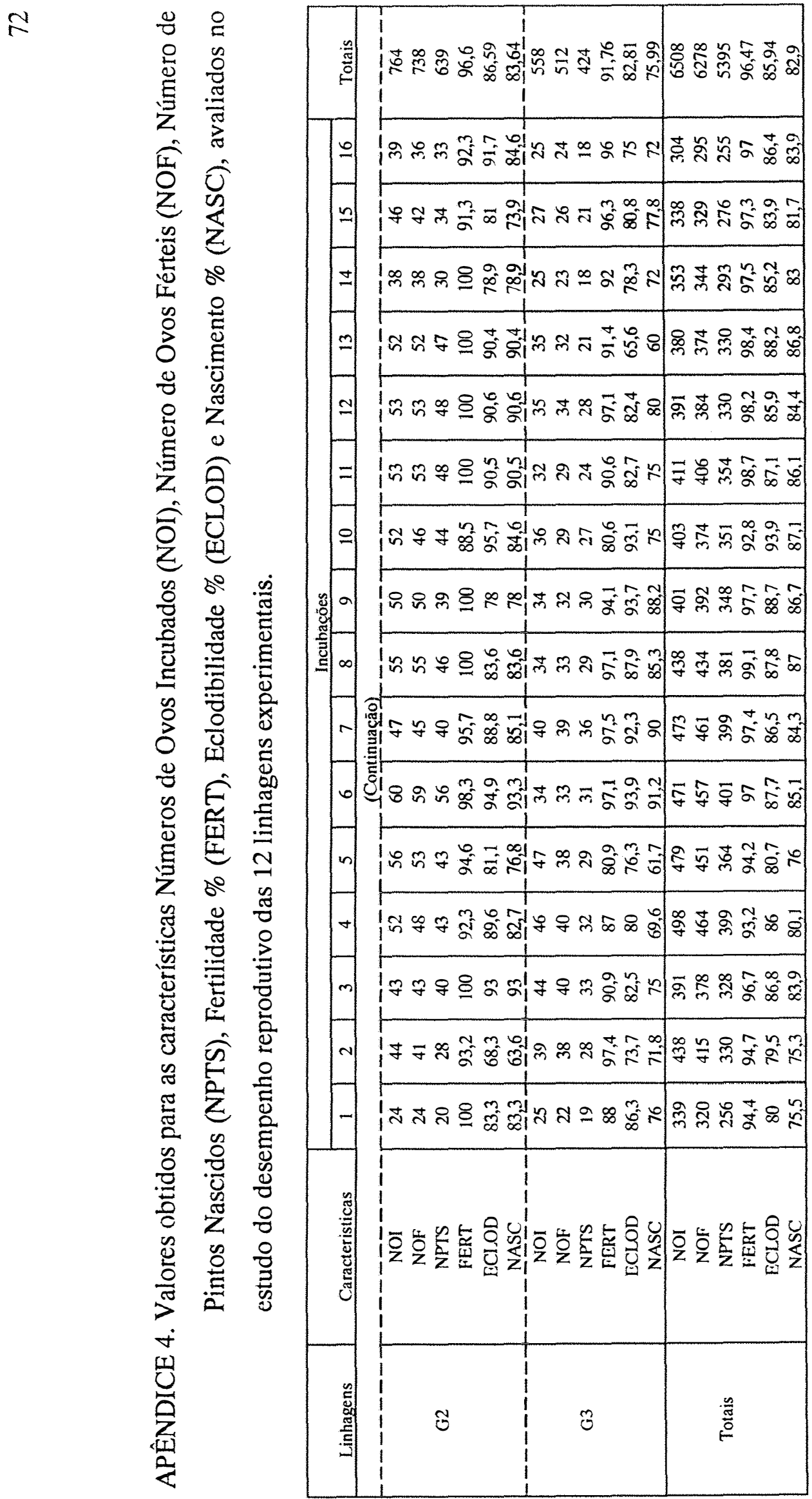


APÊNDICE 5. Leitura do padrão de bandas mais representativas obtidas nas análises de DFP das 12 linhagens experimentais

\begin{tabular}{|c|cccccccccccc|}
\hline & \multicolumn{11}{|c|}{ LINHAGENS } \\
\cline { 2 - 12 } Bandas & I1 & P1 & E1 & G1 & I2 & P2 & E2 & G2 & I3 & P3 & E3 & G3 \\
\hline 01 & 1 & 0 & 1 & 0 & 0 & 0 & 0 & 0 & 1 & 0 & 0 & 1 \\
02 & 0 & 0 & 0 & 1 & 1 & 1 & 1 & 1 & 1 & 1 & 0 & 1 \\
03 & 1 & 1 & 1 & 1 & 0 & 1 & 1 & 1 & 1 & 1 & 1 & 0 \\
04 & 1 & 1 & 1 & 1 & 0 & 1 & 1 & 0 & 1 & 1 & 1 & 0 \\
05 & 0 & 0 & 0 & 1 & 0 & 0 & 1 & 0 & 1 & 0 & 0 & 1 \\
06 & 1 & 1 & 1 & 1 & 1 & 1 & 0 & 1 & 0 & 1 & 1 & 0 \\
07 & 0 & 0 & 1 & 0 & 0 & 0 & 0 & 0 & 0 & 0 & 1 & 1 \\
08 & 0 & 1 & 0 & 1 & 1 & 0 & 1 & 1 & 1 & 1 & 1 & 1 \\
09 & 1 & 0 & 1 & 0 & 0 & 1 & 0 & 0 & 0 & 0 & 0 & 0 \\
10 & 1 & 1 & 1 & 0 & 0 & 0 & 0 & 0 & 0 & 1 & 1 & 1 \\
11 & 0 & 0 & 1 & 0 & 1 & 1 & 1 & 1 & 1 & 1 & 0 & 1 \\
12 & 0 & 1 & 0 & 0 & 0 & 1 & 0 & 1 & 1 & 1 & 1 & 0 \\
13 & 1 & 1 & 0 & 1 & 1 & 1 & 0 & 0 & 1 & 0 & 0 & 1 \\
14 & 0 & 0 & 0 & 1 & 0 & 1 & 0 & 0 & 1 & 0 & 1 & 0 \\
15 & 1 & 1 & 1 & 1 & 1 & 0 & 1 & 1 & 0 & 1 & 1 & 1 \\
16 & 0 & 0 & 0 & 0 & 0 & 0 & 0 & 0 & 0 & 1 & 0 & 0 \\
17 & 0 & 0 & 0 & 0 & 0 & 0 & 0 & 0 & 0 & 0 & 1 & 0 \\
18 & 0 & 1 & 0 & 1 & 1 & 1 & 1 & 1 & 1 & 0 & 1 & 1 \\
19 & 0 & 0 & 0 & 1 & 1 & 0 & 0 & 0 & 0 & 0 & 0 & 0 \\
20 & 1 & 1 & 1 & 0 & 0 & 1 & 1 & 0 & 1 & 1 & 0 & 0 \\
21 & 0 & 0 & 0 & 0 & 0 & 0 & 0 & 1 & 0 & 0 & 1 & 1 \\
22 & 1 & 0 & 0 & 1 & 1 & 1 & 1 & 0 & 0 & 0 & 1 & 1 \\
23 & 1 & 0 & 0 & 0 & 1 & 0 & 0 & 1 & 0 & 1 & 1 & 0 \\
24 & 1 & 0 & 0 & 1 & 0 & 1 & 1 & 0 & 1 & 1 & 1 & 1 \\
\hline
\end{tabular}


APÊNDICE 6: Composição das soluções utilizadas nas análises laboratoriais de DFP.

EDTA 2\%: $\mathrm{H}_{2} \mathrm{O} M Q$ q.s.p. $1000 \mathrm{ml}$

$20 \mathrm{~g}$ de $\mathrm{Na}_{4}$

SSC 20x: $\mathrm{H}_{2} \mathrm{O} M Q$ q.s.p. $1000 \mathrm{ml}$

$175 \mathrm{~g} \mathrm{de} \mathrm{NaCl}$

88,2 g de Citrato de Sódio

Obs: O SSC 10x foi obtido através da diluição do SSC 20x.

SDS 10\%: $\mathrm{H}_{2} \mathrm{O}$ MQ q.s.p. $1000 \mathrm{ml}$

$100 \mathrm{~g}$ de Sodium Dodecyl Sulfate

Obs: O SDS $1 \%$ foi obtido através da diluição do SDS $10 \%$.

FENOL/CLOROFÓRMIO: $100 \mathrm{~g}$ de Fenol

$96 \mathrm{ml}$ de Clorofórmio

$4 \mathrm{ml}$ de Álcool Isoamílico

$100 \mathrm{mg}$ de 8 Hidroxiquinolina

$200 \mathrm{ml}$ de Tris $\mathrm{HCl} 1 \mathrm{M} \mathrm{pH} 8,0$

TE $1 \times$ pH 8,0: $\mathrm{H}_{2} \mathrm{O}$ MQ q.s.p. $1000 \mathrm{ml}$

$10 \mathrm{ml}$ de Tris $\mathrm{HCl} 1 \mathrm{M}$ pH 8,0

$2 \mathrm{ml}$ de EDTA $0,5 \mathrm{M} \mathrm{pH} 8,0$

TAE 50x: $\mathrm{H}_{2} \mathrm{O}$ MQ q.s.p. $1000 \mathrm{ml}$

$242,2 \mathrm{~g}$ de Tris Base

$37,2 \mathrm{~g}$ de EDTA $\left(\mathrm{Na}_{4}\right)$

$57,1 \mathrm{ml}$ de Ácido Acético

Obs: O TAE $1 x$ foi obtido através da diluição do TAE 50x.

GEL DE AGAROSE 0,8\%: $\mathrm{H}_{2} \mathrm{O}$ MQ q.s.p. $1000 \mathrm{ml}$

$8 \mathrm{~g}$ de Agarose

$100 \mathrm{ml}$ de TBE $10 \mathrm{x}$

TBE 10x: $\mathrm{H}_{2} \mathrm{O}$ MQ q.s.p. $1000 \mathrm{ml}$

$12,1 \mathrm{~g}$ de Tris Base

$51,3 \mathrm{~g}$ de Ácido Bórico

$3,72 \mathrm{~g}$ de EDTA $\left(\mathrm{Na}_{2}\right)$

Obs: O TBE $1 x$ foi obtido através da diluição do TBE $10 x$.

TAMPÃO DE CORRIDA (STOP 10x): $\mathrm{H}_{2} \mathrm{O}$ MQ q.s.p. $1000 \mathrm{ml}$ $500 \mathrm{mg}$ de Bromofenol Blue

$30 \mathrm{~g}$ de Ficoll

$40 \mathrm{ml}$ de TAE $50 \mathrm{x}$ 